\title{
The Regulatory Cascade That Activates the Hrp Regulon in Erwinia herbicola pv. gypsophilae
}

\author{
R. Nizan-Koren, ${ }^{1}$ S. Manulis, ${ }^{2}$ H. Mor, ${ }^{1}$ N. M. Iraki, ${ }^{3}$ and I. Barash ${ }^{1}$ \\ ${ }^{1}$ Department of Plant Sciences, Faculty of Life Sciences, Tel-Aviv University, Tel-Aviv 69978; ${ }^{2}$ Department of Plant \\ Pathology, ARO, Volcani Center, Bet Dagan 50250, Israel; ${ }^{3}$ UNESCO Biotechnology Laboratory, Bethlehem University, \\ Bethlehem, Palestinian Authority.
}

Submitted 24 July 2002. Accepted 18 November 2002.

\begin{abstract}
The pathogenicity of Erwinia herbicola pv. gypsophilae $($ Ehg $)$ is dependent on a plasmid ( pPATH $_{\text {Ehg }}$ ) that harbors the $h r p$ gene cluster and additional virulence genes. The hrp regulatory cascade of $E$ hg comprises an $h r p X Y$ operon encoding a two-component system; hrpS encoding a transcriptional factor of the NtrC family and $h r p L$ encoding an alternative sigma factor. Results obtained suggest the following signal transduction model for activating the Hrp regulon: phosphorylated HrpY activates hrpS, HrpS activates $h r p L$, and HrpL activates genes containing "hrp box" promoter. This model was supported by studies on the effects of mutations in the regulatory genes on pathogenicity and complementation analysis. Nonpolar mutations in $h r p X$ did not affect virulence or transcription of downstream genes. Site-directed mutagenesis of the conserved aspartate 57 in HrpY suggested that its phosphorylation is crucial for activating the $h r p$ regulatory cascade. Studies on the effects of mutations in the hrp regulatory genes on transcriptional activity of downstream genes or of their isolated promoters in planta showed dependency of $\mathrm{hrpS}$ expression on active HrpY, of $h r p L$ expression on active HrpS, and of hrpN or hrpJ expression on active HrpL. These results were also partially supported by overexpression of regulatory genes under in vitro conditions. The $h r p X Y$ is constitutively expressed with high basal levels under repressive conditions, in contrast to hrpS and $h r p L$, which exhibit low basal expression levels and are environmentally regulated.
\end{abstract}

Erwinia herbicola (Pantoea agglomerans) has been isolated from widely diverse habitats, including plant surfaces, seeds, water, and humans (Gavini et al. 1989). It is particularly widespread in nature as an epiphyte on many different plants (Starr 1981). Some strains of E. herbicola have evolved into plant pathogens that incite gall formation on gypsophila (Cooksey 1986), beet (Burr et al. 1991), wisteria (Opgenorth et al. 1994), Douglas fir (DeYoung et al. 1998), and cranberry (Vasanthakumar and McManus 2001). The host range of Erwinia herbicola pv. gypsophilae (Ehg) is restricted to gypsophila (Volcani 1985), whereas the beet pathovar E. herbicola pv. betae (Ehb) elicits galls on both beet and gypsophila (Burr et al. 1991). The pathogenicity of E. herbicola pv. gypsophilae and E. herbicola pv. betae depends upon a similar large indigenous plasmid (designated as pPATH $_{\text {Eng }}$ or pPATH $\mathrm{Ehb}_{\text {}}$ ) that is present in all pathogenic, but not in nonpathogenic, strains (Manulis et al. 1991; I. Barash and S. Manulis, unpublished data). The $\mathrm{pPATH}_{\mathrm{Ehg}}$ from

Corresponding authors: I. Barash; E-mail: isaaci@ post.tau.ac.il; S. Manulis; E-mail: shulam@volcani.agri.gov.il strain Ehg824-1 (approximately $150 \mathrm{~kb}$ ) was found to harbor numerous virulence genes, including an hrp gene cluster, genes encoding Hrp-dependent outer proteins, which are responsible for pathogenicity and host specificity, and genes encoding enzymes for indole 3-acetic acid (IAA) and cytokinin biosynthesis (Clark et al. 1993; Ezra et al. 2000; Guo et al. 2002; Lichter et al. 1995a, 1995b; Mor et al. 2001; Nizan et al. 1997; Valinsky et al. 1998). Multiple and highly diverse IS elements have also been located on the pPATH $\mathrm{Phg}_{\text {and }} \mathrm{pPATH}_{\text {Ehb }}$ (Guo et al. 2002; Lichter et al. 1996) and appear to be remnants of an extensive horizontal gene transfer that has presumably taken place during the evolution of these plasmids.

hrp genes control the ability of most gram-negative phytopathogenic bacteria to cause disease and to elicit hypersensitive reactions (HR) on resistant and nonhost plants (Lindgren 1997). Molecular genetic studies have demonstrated that Hrp proteins contain components of type III secretion systems, regulatory proteins and proteinaceous elicitors of HR. In animal and plant pathogenic bacteria, the type III secretion pathway appears to be responsible for the delivery of effector proteins into eukaryotic host cells (Galan and Collmer 1999). The $h r p$ genes are generally organized in large clusters of 22 to 40 $\mathrm{kb}$ and contain six to eight complementation groups (Bonas 1994; Lindgren 1997). The nucleotide sequences of hrp gene clusters revealed high similarities among pathogens belonging to different genera, and certain genes appear to be highly conserved (Bogdanove et al. 1996). Those genes with broad conservation among many type III systems have been renamed hrc (HR and conserved genes). Earlier studies demonstrated that hrp/hrc gene clusters of Erwinia amylovora and Pseudomonas syringae are closely related and are distinct from the hrp genes of Xanthomonas campestris and Ralstonia solanacearum, which are similar to one another and form a second lineage (Bonas 1994; Laby and Beer 1992). The transcription of hrp genes is environmentally regulated and is induced in planta or in response to nutritional conditions that mimic the apoplast environment (e.g., minimal medium) (Rahme et al. 1992).

The hrp gene cluster of E. herbicola pv. gypsophilae has been completely characterized (Mor et al. 2001); it occupies approximately $25 \mathrm{~kb}$ and contains seven complementation groups. These hrp genes are remarkably similar to and collinear with those of Erwinia amylovora and Pantoea stewartii subsp. stewartii. With few exceptions, the identities of the various hrp operons of E. herbicola pv. gypsophilae-deduced proteins compared with those of E. amylovora and $P$. stewartii subsp. stewartii ranged from 70 to $88 \%$ (Mor et al. 2001). An hrp gene cluster has also been identified on the pPATH $\mathrm{Phb}_{\mathrm{E}}(\mathrm{H}$. Mor, unpublished data). It is noteworthy that the discovery of the hrp gene cluster on the $\mathrm{pPATH}_{\mathrm{Ehg}}$ has been the only report 
so far in which hrp genes were characterized on a plasmid. With the exception of the $h r p$ gene cluster of $R$. solanacearum, which resides on a 2.1-Mb megaplasmid (Genin and Boucher 2002), hrp genes in all other bacteria are located on the chromosome. Furthermore, there seems to be no report of hrpdependent gall formation associated with any other tumorigenic bacteria, including Agrobacterium tumefaciens (Laby and Beer 1992).

The two lineages of hrp genes described above also differ in their modes of regulation. Group I hrp genes in $P$. syringae, Erwinia and Pantoea spp. accommodate conserved promoters ("hrp box") that are activated by HrpL, a member of the extracytoplasmic function (ECF) family of alternate sigma factors (Wei and Beer 1995; Xiao et al. 1994). Expression of $h r p L$ is controlled by a regulatory cascade that consists of HrpS and HrpR in P. syringae (Xiao et al. 1994) and HrpS, HrpX, and HrpY in E. amylovora (Wei et al. 2000), Pantoea stewartii subsp. stewartii (Frederick et al. 1993; Merighi et al. 2001), and E. herbicola pv. gypsophilae (Mor et al. 2001). Xanthomonas spp. and $R$. solanacearum of Group II hrp genes share a common two-component response regulator, encoded by $h r p G$ and an AraC family regulator named $h r p X v$ in Xanthomonas spp. (Wengelnik and Bonas 1996) and hrpB in R. solanacearum (Genin et al. 1992). It has recently been demonstrated that contact between $R$. solanacearum and a plant causes strong induction of $h r p$ regulatory gene expression through a complex regulatory cascade (Aldon et al. 2000; Brito et al. 2002).

The present study was undertaken to determine the order of the steps in the regulatory cascade that leads to hrp gene activation in E. herbicola pv. gypsophilae. Preliminary results of this study have been reported previously (Nizan-Koren et al. 2001).

\section{RESULTS}

Sequence analysis of the $h r p$ regulatory region.

The $h r p$ regulatory region was subcloned from the $\mathrm{pPATH}_{\mathrm{Ehg}}$ into pLAFR3 to yield pMBN-H6.4 (Fig. 1). The DNA se- quence of pMBN-H6.4 was determined previously (Mor et al. 2001) and was submitted to GenBank as accession no. AF272053. The sequence revealed four open reading frames (ORFs) between the hrpJ and hrpA operons; they have been designated as $h r p L, h r p X, h r p Y$, and $h r p S$. All the ORFs in pMBN6.4H are transcribed from right to left, whereas hrpJ is transcribed in the opposite direction (Fig. 1). The four regulatory genes of E. herbicola pv. gypsophilae (Ehg) are highly similar to and colinear with those of E. amylovora and P. stewartii subsp. stewartii (Mor et al. 2001). The hrpL gene exhibits $77 \%$ and $80 \%$ identity with the HrpL proteins of E. amylovora and $P$. stewartii subsp. stewartii, respectively. It is located 253 bp from the start of $h r p J$. It contains a $\sigma^{54}$ consensus box and encodes a predicted protein of $23 \mathrm{kDa}$ that is homologous to alternate sigma factors of the ECF $\sigma^{70}$ subfamily (Lonetto et al. 1994). The $h r p X$ ORF is located $145 \mathrm{bp}$ from the stop codon of hrpL (Fig. 1) and possesses a $\sigma^{70}$ consensus sequence. Comparison of the predicted amino acid sequences of HrpX and HrpY with sequences in the data base revealed significant similarities with many two-component regulatory proteins including, for example, the VsrA/VsrD of Ralstonia solanacearum, which regulates virulence gene expression (Huang et al. 1995). The closest homologies observed were those with the predicted amino acids of HrpX and HrpY of P. stewartii (79 and $88 \%$ identity, respectively) and E. amylovora (72 and $75 \%$ identity, respectively) (Mor et al. 2001). HrpX is a 55.5$\mathrm{kDa}$ protein with no transmembrane domains. Similarly to HrpX of E. amylovora and P. stewartii, the HrpX of Ehg carries two PAS domains. The HrpY appears to be a $24-\mathrm{kDa}$ cytoplasmic response regulator of the LuxR family of bacterial regulatory proteins (Henikoff et al. 1990). Its N-terminus harbors the conserved phosphoryl-acceptor domain D57, which is the putative site for phosphorylation. The short interspace (34 bp) between $h r p X$ and $h r p Y$, the lack of any detectable promoter downstream to the hrpX promoter, and the high homology between these genes and the $h r p X Y$ of $E$. amylovora suggest that, similar to the latter bacterium, the two genes constitute an operon.

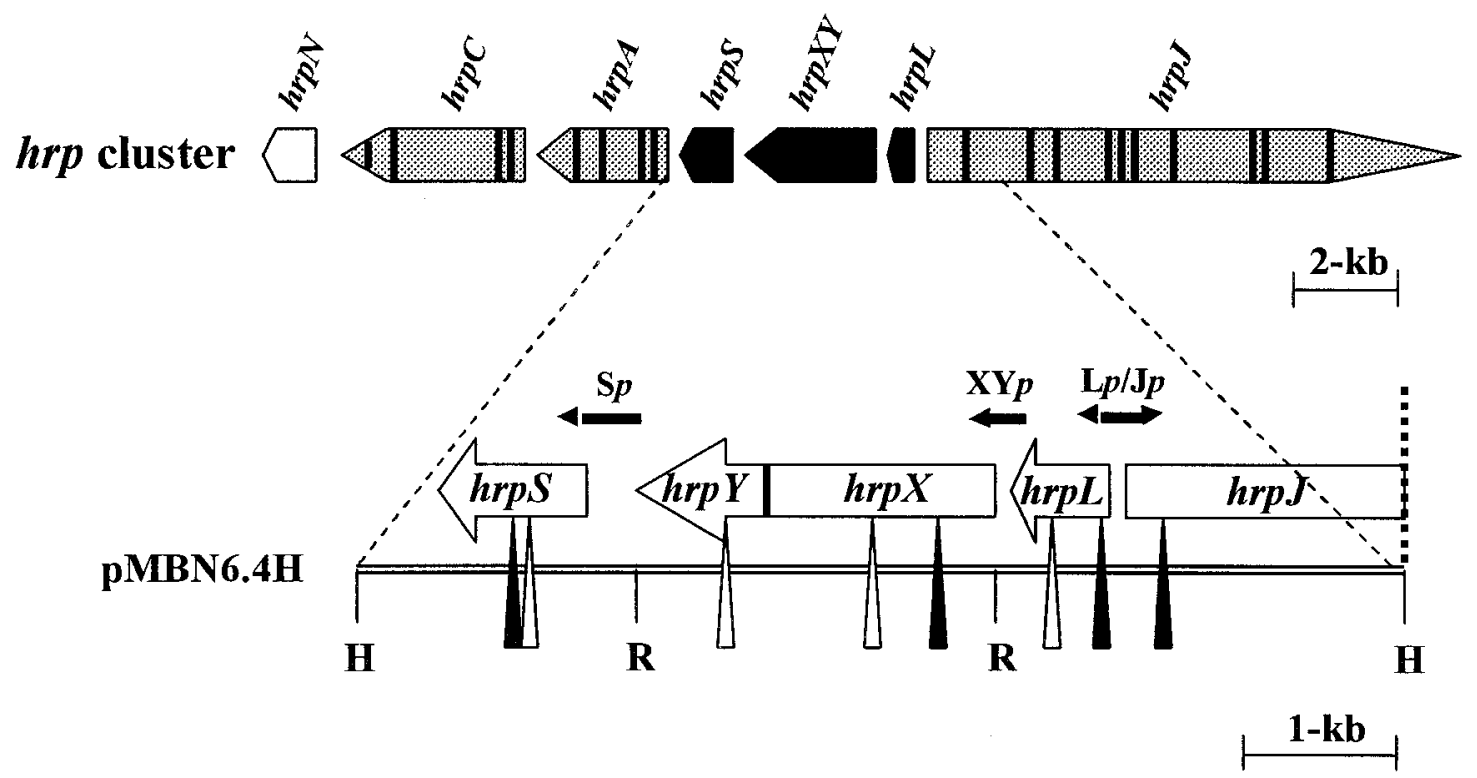

Fig. 1. Physical map of the hrp gene cluster and hrp regulatory region in Erwinia herbicola pv. gypsophilae strain Ehg824-1. The regulatory region and part of the $h r p J$ operon were subcloned from the pPATH ${ }_{\text {Eh }}$ into pLAFR3 to yield pMBN-H6.4. The regulatory genes were composed of $h r p L$, the $h r p X Y$ operon, and $h r p S$. Arrows show the transcriptional orientation. Black triangles indicate Tn3-Spice insertions in which the transcriptional orientation of the inaZ reporter gene was aligned with the gene promoter. Open triangles denote mini-Tn 10 insertions, with the exception of $h r p Y$ in which a $\mathrm{Km}^{\mathrm{r}}$ cassette was inserted. The top short black lines indicate promoter regions that were subcloned into pPROBE-GI or pPROBE-GI'. L $p / \mathrm{J} p$ indicates promoters of $h r p L / h r p J$ that are transcribed in opposite directions, $\mathrm{XY} p$ indicates promoter of the $h r p \mathrm{XY}$ operon, and $\mathrm{S} p$ indicates promoter of $h r p S . \mathrm{H}=H i n \mathrm{dIII}, \mathrm{R}=$ EcoRI. 
The HrpS of Ehg shows the highest sequence similarities with HrpS of E. amylovora and P. stewartii subsp. stewartii ( 83 and $79 \%$ amino acid identity, respectively). The ORF has a predicted protein of $36.3 \mathrm{kDa}$ and possesses a $\sigma^{70}$ consensus sequence. HrpS has homology to members of the NtrC family that act as $\sigma^{54}$-dependent enhancer binding proteins (Morret and Segovia 1993). However, it lacks the receiver domain that is characteristic of other enhancers of this family.

\section{Genetic characterization of the $h r p$ regulatory genes.}

The hrp regulatory region in pMBN-H6.4 was mutagenized with either the transposon-reporter pTn3-Spice or mini-Tn10$\mathrm{Km}$ (Fig. 1), and mutations in the different genes of the regulatory cascade were isolated and were located as described below. All the insertion mutants obtained with Tn3-Spice in $h r p L$, $h r p S$, and $h r p X$ were nonpathogenic and eliminated the HR response on tobacco leaves. No Tn3-Spice insertion could be recovered in $h r p Y$ during the mutagenesis procedure. Similarly, insertions of mini-Tn $10-\mathrm{Km}$ into $h r p L$ and $h r p S$, as well as insertion of a $\mathrm{Km}$ cassette into $\mathrm{hrpY}$, rendered these mutants nonpathogenic. In contrast to pTn3-Spice, insertion mutations of mini-Tn $10-\mathrm{Km}$ in $h r p X$ did not exhibit any effect on pathogenicity (Table 1). This result was repeated with 10 different mini-Tn $10-\mathrm{Km}$ mutations of $h r p X$ that were marker exchanged into E. herbicola pv. gypsophilae. As indicated above, hrpXY appears to constitute an operon. Therefore, the mutations obtained by mini-Tn $10-\mathrm{Km}$ in $h r p X$ are most likely nonpolar, in contrast to the polar mutations obtained with Tn3-Spice. A similar phenomenon in which transposon-induced mutations permit the expression of downstream genes in operons has been frequently observed with TnphoA in E. amylovora (Wei et al. 2000).

Plasmids expressing $h r p Y, h r p S$, and $h r p L$ from a constitutive lac promoter were introduced in trans into each of the abovementioned mutants, and the transconjugants were then tested for restoration of pathogenicity. Gall formation on gypsophila cuttings by all the nonpathogenic mutants obtained with mini-Tn10$\mathrm{Km}$ (or the $\mathrm{Km}$ cassette for $h r p Y$ ) were restored to the size of the wild-type strain with expressed $h r p L$ (Table 1). Mutants in $h r p Y$ and $h r p S$ but not in $h r p L$ were fully complemented by expressed $h r p S$. Finally, expressed $h r p Y$ could complement $h r p Y$ mutation but not $h r p S$ or $h r p L$ mutants. Identical complementation results were obtained with the Tn3-Spice mutants. The latter included complementation of the hrpX mutant that was nonpathogenic with the Tn3-Spice insertion. The results obtained led us to hypothesize that $\mathrm{HrpX}$ is dispensable for pathogenicity, whereas HrpY is indispensable. HrpY activates transcription of $h r p S$, and HrpS activates transcription of hrpL. Constitutive expression of HrpL is presumably sufficient to activate all the virulence genes containing hrp box promoter.

Table 1. Pathogenicity of mutants in $h r p$ regulatory genes and their complementation

\begin{tabular}{lcccc}
\hline & \multicolumn{4}{c}{ Expressed gene for complementation } \\
\cline { 2 - 5 } Mutated gene $^{\mathbf{a}}$ & None & lacp-hrpY & lacp-hrpS & lacp-hrpL \\
\hline $\operatorname{hrp}_{\mathrm{Tn} 10}$ & $+^{\mathrm{c}}$ & + & + & + \\
$\operatorname{hrp}_{\mathrm{Km}}$ & - & + & + & + \\
$\operatorname{hrp}_{\mathrm{Tn} 10}$ & - & - & + & + \\
$\operatorname{hrp}_{\mathrm{Tn} 10}$ & - & - & - & + \\
\hline
\end{tabular}

${ }^{\mathrm{a}}$ Mutations were generated by saturation mutagenesis of pMBN-H6.4 with the transposon mini-Tn $10-\mathrm{km}$ or by introducing a kanamycinresistant cassette (in the case of $h r p Y$ ). Abbreviations of marker exchanged mutants: $h r p X_{\mathrm{Tn} 10}=E h g \mathrm{MxX} \mathrm{X}_{\mathrm{Tn} 10} ; h r p Y_{\mathrm{Km}}=E h g \mathrm{Mx} \mathrm{Y}_{\mathrm{Km}}$; $h r p S_{\mathrm{Tn} 10}=E h g \mathrm{MxS}_{\mathrm{Tn} 10}$; and $h r p L_{\mathrm{Tn} 10}=E h g \mathrm{MxL}_{\mathrm{Tn} 10}$.

${ }^{\mathrm{b}}$ Abbreviations of plasmids: lacp-hrpY = pVSPhrpY; lacp-hrpS = $\mathrm{pVSP} h r p S$; lacp- $h r p L=\mathrm{pVSP} h r p L$.

${ }^{c}+$ designates gall formation, and - designates nonpathogenic.
Effect of lacp-hrpL, lacp-hrpS, and lacp-hrpY on hrp gene expression.

To evaluate the above-mentioned hypothesis further, we studied the impact of overexpressed regulatory genes on the transcriptional activity of other regulatory and $h r p$ genes. To demonstrate maximal effect by overexpression, we initially searched for environmental conditions in which the transcription of $h r p$ genes is likely to be highly repressed. Transcriptional activity of $h r p$ genes is known to be induced under conditions that mimic the plant apoplast environment, such as minimal media, as opposed to a repressive effect of rich media (Rahme et al 1992). Therefore, we compared the transcriptional activities of bacteria grown in minimal and rich media with that of bacteria grown in the apoplast of gypsophila stems. Expression of $h r p J$ was used as a representative of the $h r p$ gene cluster. For this purpose, we used an EhgMx33 mutant in which the inaZ reporter is under the $h r p J$ promoter. The results illustrated in Table 2 show that ice nucleation in bacteria grown on Luria-Bertani (LB) agar was 3, 2.7, and 2 orders of magnitude lower than that in bacteria grown in gypsophila stems, minimal M-9, and minimal A agar media, respectively. Consequently, LB agar was selected as a repressive medium for the overexpression studies.

Overexpression of $h r p$ regulatory genes was achieved by mobilizing lacp-hrpL, lacp-hrpS, and lacp-hrpY fusions in trans into E. herbicola pv. gypsophilae strains containing the inaZ reporter in each of the different regulatory genes and in $h r p N$ (encoding for harpin). The results shown in Figure 2 demonstrate that Plac-hrpL up-regulated the transcription of $h r p N$ by 3.5 orders of magnitude, as compared with the control, but did not significantly affect the transcription of any of the other regulatory genes, namely, $h r p S, h r p X$, and $h r p L$. lacp$h r p S$ stimulated the transcription of $h r p L$ (by three orders) and $h r p N$ (by 2.5 orders). Quite surprisingly however, $h r p X$ and $h r p S$ were turned up by 2 and 1.5 orders of magnitude, respectively, by lacp-hrpS. The latter autoregulatory loop, which was obtained under in vitro conditions, may not be in accordance with the proposed linear model, namely, $h r p Y \rightarrow h r p S \rightarrow$ $h r p L \rightarrow$ genes containing " $h r p$ box" promoter. In contrast to overexpressed $h r p S$ and $h r p L$, lacp-hrpY did not significantly induce the transcription of any of the tested $h r p$ genes under the repressive conditions employed (Fig. 2). It is noteworthy that the expression levels of $h r p X Y$ in bacteria grown on LB agar was significantly higher than those of $h r p S$ and $h r p L$ (Fig. 2, control).

\section{Effect of mutations on expression}

of $h r p$ regulatory genes during bacterial growth in planta.

Results from overexpression of the regulatory genes (Fig. 2) left some unresolved questions. For example, does the "autoregulatory loop" caused by lacp-hrpS operate under in vivo conditions as well? Or, why does the lacp-hrpY not stimulate expression of the downward genes of the regulatory cascade? To avoid potential artifacts that could be introduced by the arti-

Table 2. Effect of different environments on transcriptional activity of hrpJ-ina $\mathrm{Z}^{\mathrm{a}}$

\begin{tabular}{lc}
\hline External environment $^{\mathbf{b}}$ & Log (ice nuclei/cell) \\
\hline LB medium & $-5.1 \pm 0.20$ \\
MinA medium & $-3.0 \pm 0.25$ \\
M-9 medium & $-2.3 \pm 0.15$ \\
Gypsophila paniculata stems & $-1.6 \pm 0.30$ \\
\hline
\end{tabular}

${ }^{-}$hrpJ-inaZ $($EhgM $\times 33)$ was obtained by $\mathrm{pTn} 3$-Spice mutagenesis as described elsewhere (Nizan et al. 1997). In this mutant, inaZ is under hrpJ promoter.

${ }^{\mathrm{b}} \mathrm{LB}=$ Luria-Bertani agar; MinA = minimal A agar; M-9 = minimal agar. 
ficial conditions, we examined the interaction among the regulatory genes under natural conditions in planta. As shown in Table 2, under these conditions, there was maximal induction of $h r p$ genes expression (Table 2). Double mutants, in which the ice nucleation reporter gene inaZ was inserted into one regulatory gene and a kanamycin-resistance cassette $(\mathrm{Km})$ into another, were constructed as described below. The bacteria were grown in gypsophila stems at $25^{\circ} \mathrm{C}$ for $16 \mathrm{~h}$ prior to determination of ice nucleation activity. The results shown in Figure 3 demonstrate that inactivation of $h r p X$ by $\mathrm{Km}$ insertion did not significantly affect the transcriptional activity (ice nucleation) of $h r p S$ or $h r p L$ nor that of the nonregulatory $h r p$ genes $h r p J$ and $h r p N$, as compared with the control. In contrast, inactivation of $h r p Y$ reduced the expression of $h r p S$, $h r p L, h r p J$, and $h r p N$ by $2.1,2.3,2.3$, and 2.1 orders of magnitude, respectively. Mutants carrying $h r p S:: K m$ exhibited reduced expression of $h r p L, h r p J$, and $h r p N$ by $2.2,2.1$, and 2.8 orders, respectively, but did not significantly affect $h r p X$. Inactivation of $h r p L$ reduced the expression of $h r p J$ and $h r p N$ by 2 and 3.8 orders, respectively, but did not significantly affect $h r p X$ and $h r p S$. As indicated above, since $h r p X Y$ appears to constitute an operon, all the transcription activity recorded for the $h r p X$ promoter can be considered identical for $h r p Y$. These results are in accordance with our hypothesized model and indicate again that $h r p X$ is dispensable, whereas $h r p Y$ is indispensable, for activation of the hrp genes.

\section{Effects of mutations in the regulatory genes} on transcriptional activity of isolated promoters in planta.

The following experiments were undertaken to demonstrate that the genes of the regulatory cascade act directly on the promoters that they would be expected to activate according to our hypothesized model and to rule out artifacts due to the possible action of distant promoters. The promoters of $h r p X Y$, hrpS, $h r p L$, and $h r p J$, respectively (Fig. 1), were cloned into the promoter probe plasmids pPROBE-GI or pPROBE-GI' to yield pPROBE-hrpXYp, pPROBE-hrpSp, pPROBE-hrpLp, and
pPROBE-hrpJp as described below. Each of these plasmids was mobilized in trans into mutants of E. herbicola pv. gypsophilae that contained a $\mathrm{Km}$ insertion in a different regulatory gene and into a wild-type strain as a control. The transconjugants were then grown in gypsophila cuttings as described in the previous section, and the ice nucleation activity stimulated by the promoters was recorded after $16 \mathrm{~h}$.

Results in Figure 4 demonstrate that mutations in $h r p Y$, $h r p S$, and $h r p L$, but not in $h r p X$, significantly reduced the expression of the $h r p J$ promoter. Mutations in $h r p Y$ and $h r p S$, but not in $h r p X$ or $h r p L$, significantly reduced the expression of the $h r p L$ promoter (by 1.9 orders of magnitude). Finally, only mutation in $h r p Y$ could significantly reduce the expression of the hrpS promoter. These findings clearly indicate that HrpY, $\mathrm{HrpS}$, and $\mathrm{HrpL}$, respectively, are directly involved in activation of the promoters of $h r p S, h r p L$, and $h r p J$. HrpS and HrpL most likely mediate the effect of the $h r p Y$ mutation on the promoters of $h r p L$ and $h r p J$, respectively, whereas HrpL most likely mediates the effect of hrpS mutation on the promoter of $h r p J$. None of the mutations in the hrp regulatory genes elicited any effect on promoter expression of its upstream genes in the proposed regulatory cascade, including the $h r p X Y$ promoter (results not shown).

\section{The $h r p X Y$ operon is constitutively expressed.}

Results presented in Figure 2 showed that the expression level of $h r p X$ in bacteria grown on LB agar was at least 1.5 orders of magnitude higher than the basal expression level of the other tested hrp genes. Furthermore, overexpression by lacp$h r p Y$ under repressive conditions (Fig. 2) did not elicit any significant stimulation of the downward genes, i.e., $h r p S$, $h r p L$, or $h r p N$, although their transcription was dependent on active hrpY (Figs. 3 and 4). These results led us to postulate that expression of $h r p X Y$ is constitutive and is not affected by the external environment. To test this hypothesis, we compared the transcriptional activity of $h r p X Y$ promoter with that of $h r p S$ promoter in bacteria grown under repressive conditions (i.e.,

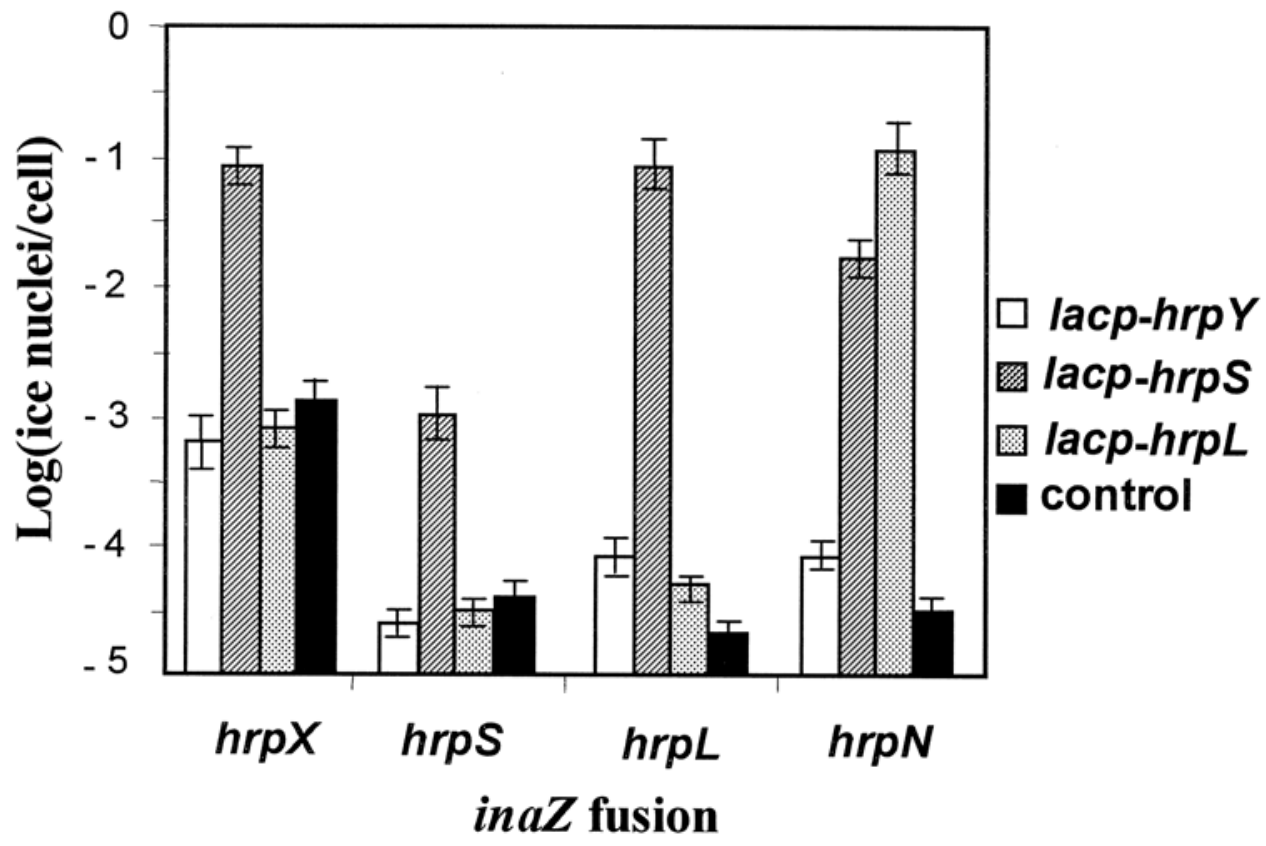

Fig. 2. Effect of overexpression of the $h r p$ regulatory genes on transcriptional activity of $h r p$ genes. Each of the following pVSP61 derivatives harboring Plac-hrpL (pVSPhrpL), Plac-hrpS (pVSPhrpS), and Plac-hrpY (pVSPhrpY) was mobilized into Erwinia herbicola pv. gypsophilae (Ehg824-1) mutants containing the inaZ reporter gene in $h r p X\left(E h g \mathrm{MxX} \mathrm{Tn}_{\mathrm{Tn}}\right), h r p S\left(E h g \mathrm{MxS}_{\mathrm{Tn} 3}\right), h r p L\left(E h g \mathrm{MxL}_{\mathrm{Tn} 3}\right)$, and $h r p N(E h g \mathrm{M} \times 14)$. Mutants containing the vector pVSP61 served as a control for each of the tested $h r p$ genes.The transconjugants and the respective controls were grown for $16 \mathrm{~h}$ in $\mathrm{LB}$ broth at $28^{\circ} \mathrm{C}$, and ice nucleation was determined. Results presented are an average of three replicates per treatment. At least two independent experiments were carried out with similar results. 
LB agar) and in bacteria grown under inductive conditions (i.e., gypsophila stems). The results presented in Figure 5 demonstrate that the expression level of $h r p X Y$ promoter on LB agar and in planta were similar. In contrast, the transcriptional activity of $h r p S$ promoter was more than 2 orders of magnitude higher during growth in planta than during growth on LB agar. The behavior of the hrpL promoter under the two growth conditions was similar to that of $h r p S$ (data not shown).

\section{Phosphorylation of HrpY is mandatory}

for transcriptional activation of $h r p S$.

The results obtained indicate that, although stimulation of hrpS expression by gypsophila cuttings was dependent on an active $h r p Y$, overexpression of the latter gene in LB medium did not stimulate hrpS transcription (Fig. 2). These findings suggest that the basal level of HrpY is sufficient for hrpS activation and raise the possibility that structural modification of HrpY, rather than its level of expression (beyond the basal amount), might be responsible for $h r p S$ activation. As indicated above, HrpY belongs to the family of response regulators of the two-component system that contains a conserved aspartate residue in codon 57 (D57) for phosphorylation. Consequently, the role of HrpY phosphorylation in activation of hrpS was tested by conversion of D57 into alanine (A57) or glutamate (E57). The procedure for site-directed mutagenesis is described below. The double mutants Ehg $\mathrm{MxS}_{\mathrm{Tn} 3} / \mathrm{Y}-\mathrm{A} 57$ and Ehg MxS $\mathrm{S}_{\mathrm{Tn} 3} / \mathrm{Y}$-E57 containing inaZ in hrpS and mutations in codon 57 of $h r p Y$ were used for studies on stimulation of $h r p S$ by HrpY. EhgMxS $\mathrm{S}_{\mathrm{Tn} 3}$ was used as a control. Bacteria were grown in gypsophila stems as described above. The results pre- sented in Figure 6 indicate that conversion of the aspartate at the codon residue 57 of $\mathrm{HrpY}$ into either alanine or glutamate reduced the transcription of $h r p S$ by more than 5 orders of magnitude and almost completely eliminated $h r p S$ expression.

\section{DISCUSSION}

In this study, we investigated the hierarchical order through which genes of the hrp regulatory cascade of E. herbicola pv. gypsophilae activate the Hrp regulon. Sequence analysis indicated high similarity and colinearity in protein sequence among the regulatory genes of E. herbicola pv. gypsophilae, $P$. stewartii, and E. amylovora (Mor et al. 2001). Nevertheless, differences in their modes of action do exist. The obtained results appear to favor a linear cascade signal transduction scheme that leads to activation of the Hrp regulon (Fig. 7). Accordingly, phosphorylation of HrpY upregulates the expression of $h r p S$, and HrpS together with sigma 54 activates hrpL. HrpL is responsible for activation of genes controlled by the hrp regulon. Essentially, a similar model was recently proposed also for $P$. stewartii subsp. stewartii (Merighi et al. 2001). In contrast to $E$. herbicola pv. gypsophilae and $P$. stewartii, a different model has been suggested for E. amylovora, in which HrpS and HrpY are bound simultaneously to the $h r p L$ promoter and then interact with the RNA polymerase- $\sigma^{54}$ complex to drive transcription of hrpL (Wei et al. 2000). In Pseudomonas syringae, HrpR and $\mathrm{HrpS}$ are homologues that function as positive regulatory factors for $h r p L$ promoter (Grimm et al. 1995). Like the HrpS of Erwinia and Pantoea spp., both HrpR and HrpS are structurally related to enhancer binding proteins that function with $\sigma^{54}$

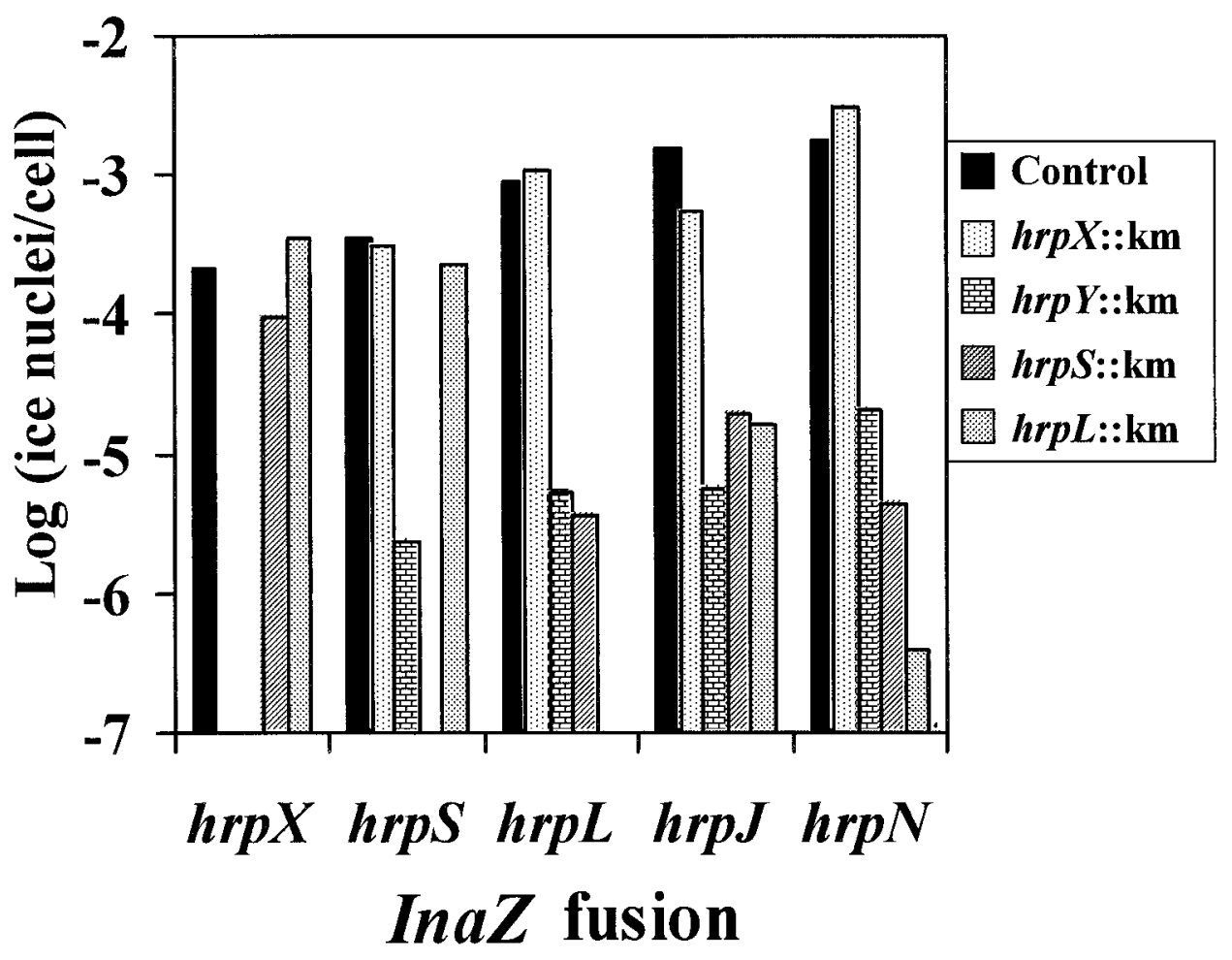

Fig. 3. Effect of mutations in hrp regulatory genes on hrp genes expression in planta. Double mutants in which one gene of the regulatory cascade was disrupted by a Km insertion and another hrp gene carried the ice nucleation reporter inaZ were constructed. The hrp genes shown in the abscissa harbor the inaZ reporter gene. Each column represents a double mutant. The patterns assigned to each Km-inserted $h r p$ gene are illustrated by small squares on the right side. The double mutants in which $h r p X, h r p S$, $h r p L, h r p J$, or $h r p N$ contain the inaZ reporter and and the Km insertion in the other $h r p$ genes are

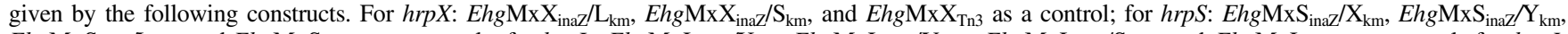
$E h g \mathrm{MxS}_{\mathrm{inaZ}} \mathrm{L}_{\mathrm{km}}$, and $E h g \mathrm{MxS}_{\mathrm{Tn} 3}$ as a control ; for $h r p L$ : EhgMxL $\mathrm{MnZ}_{\mathrm{ina}} / \mathrm{X}_{\mathrm{km}}, E h g \mathrm{MxL}_{\mathrm{inaZ}} / \mathrm{Y}_{\mathrm{Km}}, E h g \mathrm{MxL}_{\mathrm{inaZ}} / \mathrm{S}_{\mathrm{Km}}$, and $E h g \mathrm{MxL} \mathrm{Tn}_{3}$ as a conrol; for $h r p J$ : $E h g \mathrm{MxJ}_{\text {inaZ }} / \mathrm{X}_{\mathrm{km}}, E h g \mathrm{MxJ}_{\text {inaZ }} / \mathrm{Y}_{\mathrm{km}}, E h g \mathrm{MxJ}_{\text {inaz }} / \mathrm{S}_{\mathrm{km}}, E h g \mathrm{MxJ}_{\mathrm{inaZ}} / \mathrm{L}_{\mathrm{km}}$, and $E h g \mathrm{Mx} 33$ as a control ; for $h r p N$ : $E h g \mathrm{MxN}_{\mathrm{inaZ}} / \mathrm{X}_{\mathrm{Km}}, E h g \mathrm{MxN}_{\mathrm{inaZ}} / \mathrm{Y}_{\mathrm{km}}$, $E h g \mathrm{MxN}_{\text {inaZ }} / \mathrm{S}_{\mathrm{Km}}, E h g \mathrm{MxN} \mathrm{N}_{\text {inaz }} / \mathrm{L}_{\mathrm{km}}$, and $E h g \mathrm{M} \times 14$ as a control. At least two independent experiments were carried out with similar results. The standard deviations in these experiments ranged between 0.15 to $0.40 \log$ (ice nuclei per cell). 
promoters. It has been recently established that HrpR and HrpS physically interact to regulate the $\sigma^{54}$-dependent $h r p L$ promoter in P. syringae strains (Hutchison et al. 2001).

Several lines of evidence support the proposed linear cascade model of hrp regulation in E. herbicola pv. gypsophilae. $h r p S$ expressed by lac promoter under in planta conditions completely overrides nonpathogenic hrpY mutants, whereas $h r p L$ expressed by lac promoter completely overrides nonpathogenic $h r p Y$ and $h r p S$ mutants (Table 1). In contrast, hrpY expressed by lac promoter did not even slightly override hrpS mutant, a result that could be expected if HrpY directly and independently affects $h r p L$. A nonpolar mutation in $h r p X$ did not
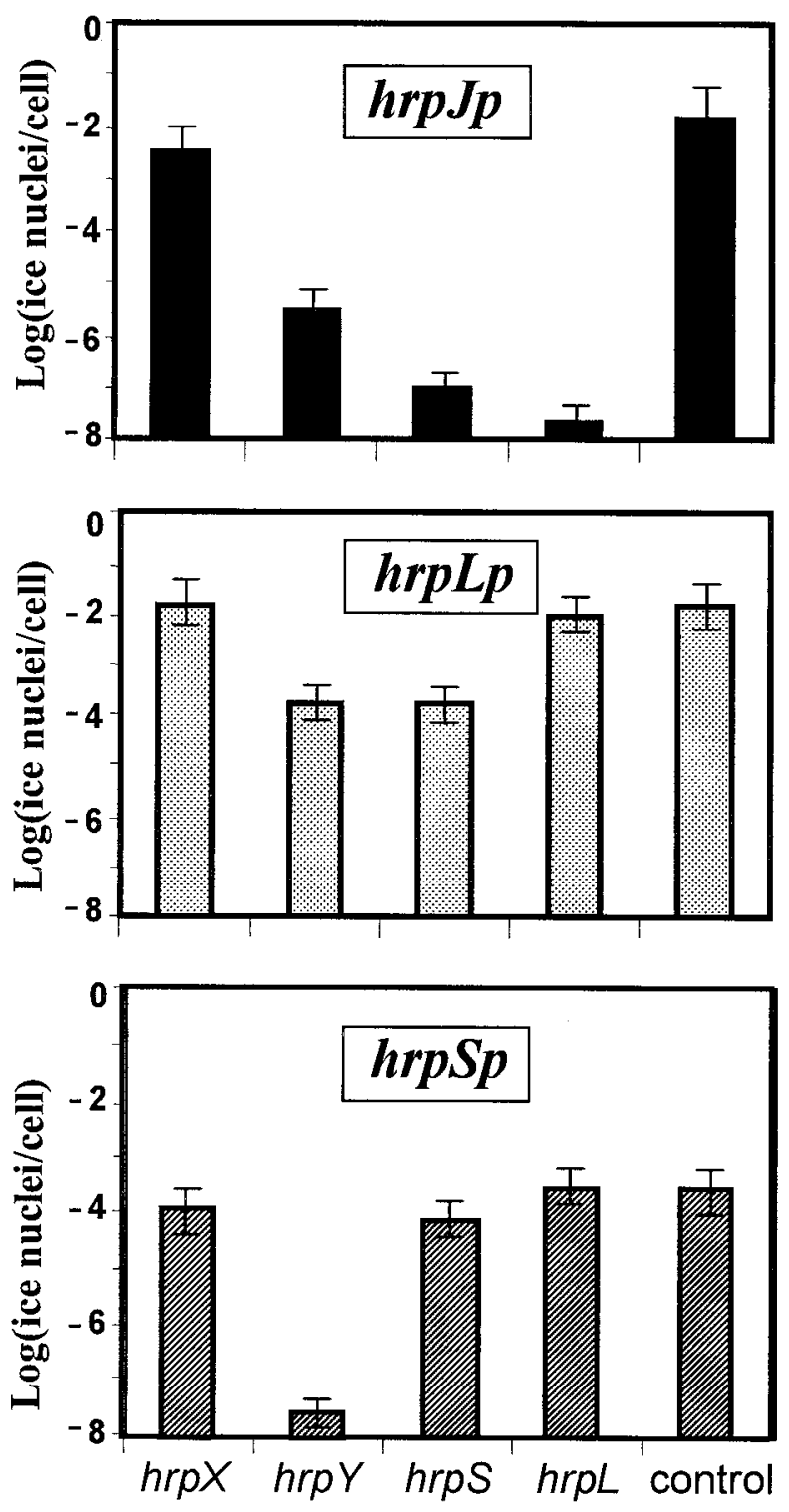

Km mutation

Fig. 4. Effect of mutations in hrp regulatory genes on expression of cloned hrp promoters in planta. The promoters of $h r p J, h r p L, h r p S$, and $h r p X Y$ were cloned into either pPROBE-GI or pPROBE-GI' to obtain pPROBE- $h r p X Y p$, pPROBE-hrpSp, pPROBE-hrpLp, and pPROBEhrpJp. Each of these plasmids was mobilized in trans into the following Erwinia herbicola pv. gypsophilae mutants: hrpX, Ehg $\mathrm{MxX}_{\mathrm{Tn} 10}$; hrpY, EhgMxY $\mathrm{Km}_{\mathrm{Km}} ;$ hrpS, EhgMxS $\mathrm{Tn}_{\mathrm{T} 10} ;$ hrpL, EhgMxL $\mathrm{Mn}_{\mathrm{Tn} 0}$; and control, Ehg824-1. The transconjugants were grown in gypsophila stems and ice nucleation activity was determined was carried out according to Lindgren and associates (1989). elicit any effect on virulence, indicating that $h r p X$ is dispensable. In comparison, in $P$. syringae, in which HrpR and HrpS simultaneously affect $h r p L, h r p S$ expressed from a strong promoter on a multicopy plasmid could function only as a weak activator of $h r p L$ (Hutchison et al. 2001). The ability of lacp::hrpS to fully restore pathogenicity of $h r p Y$ mutant may not be assigned to an excessive HrpS, since the expression level of the hrp-regulated gene $h s v G$ from $E$. herbicola pv. gypsophilae in planta was the same in the presence of or the absence of lacp::hrpS (Valinsky et al. 2002). Thus, the expression of hrp-regulatory genes in planta seems to reach the necessary threshold level for induction of full pathogenicity provided that an adequate level of phosphorylated HrpY is formed.

The effects of mutations in the hrp regulatory genes on their expression in planta (Fig. 3) showed dependency of hrpS expression on active HrpY, of $h r p L$ expression on active HrpY and HrpS, and of $h r p N$ or hrpJ expression on active HrpY, HrpS, and HrpL. None of the above genes exhibited any dependency of their transcription on active HrpX. Similar results were obtained when the transcriptional activities of cloned promoters of $h r p S$, $h r p L$, and $h r p J$ were fused upstream to the inaZ reporter and were introduced in trans to various mutants of the regulatory genes (Fig. 4). Thus, $h r p Y$ mutant reduced the expression of $h r p S$ promoter as well as the promoters of the downstream genes of the cascade. However, HrpS and HrpL, respectively, most likely mediate the effect of HrpY on hrpL and hrpJ. Similarly, hrpS mutant reduced the expression of the $h r p L$ and $h r p J$ promoters, whereas $h r p L$ mutant merely reduced the expression of the $h r p J$ promoter. None of the mutants exhibit any effect on expression of their upstream genes of the regulatory cascade. These results can be best explained by assuming a unidirectional and sequential cascade mode of operation.

A significant feature of the proposed model is that the $h r p X Y$ promoter is not environmentally regulated (Fig. 5); furthermore, its basal level of expression under repressive conditions is at least 10-fold higher than those of hrpS or hrpL (Fig. 2). In addition, overexpression of $h r p Y$ in LB medium did not stimulate the transcription of $h r p S$, $h r p L$, and $h r p J$. These results led us to postulate that HrpY cannot be phosphorylated under repressive conditions, and phosphorylation of HrpY, rather than its expression level, is the key step in activation of hrpS. The latter premise was supported by the finding that site-directed mutagenesis of HrpY in its conserved aspartate residue (D57), which is supposed to mediate phosphorylation (Hoch and Silhavy 1995), drastically reduced the activation of $h r p S$ (Fig. $6)$. Although the possibility that the conversion of the D57 into either alanine or gluatmate resulted in changes in the tertiary structure of the polypeptide rather than its phosphorylation cannot be entirely excluded, the fact that inactivation was carried out by substitution of two structurally different amino acids as well as the high constitutive level of HrpY strongly support the phosphorylation hypothesis. It is noteworthy that expression of hrpXY by E. amylovora and P. stewartii is environmentally regulated. (Merighi et al. 2001; Wei et al. 2000). However, similar to E. herbicola, the basal expression level of $h r p Y$ in these two bacteria is considerably higher than levels of the other $h r p$ genes. Interestingly, similarly to the $h r p X Y$ of $E$. herbicola, the expression of the hrpRS operon in P. syringae has been shown to be constitutive (Hutcheson et al. 2001).

The main finding, which differs between the models proposed for E. herbicola pv. gypsophilae and E. amylovora, is based on a single $h r p Y$ mutation that, in E. amylovora, abolishes $h r p L$ expression but does not appear to affect $h r p S$ (Wei et al. 2000). Similar to E. herbicola, overexpression of HrpS also exerted a significant effect on $h r p L$ expression in E. amylovora. The independence of $h r p S$ from the $h r p Y$ expression in E. amylovora led Wei and associates (2000) to propose that 
hrpXY is not epistatic to hrpS and that environmental signals may go to hrpS through a different pathway than through $h r p X Y$. Consequently, they concluded that HrpS and HrpY act together on the hrpL promoter. In contrast, in E. herbicola pv. gypsophilae, the transcription of $h r p S$ seems to be highly dependent on phosphorylated HrpY (Fig. 6). Although it is quite possible that other effectors that affect the transcription or posttranscription of $h r p S$ or $h r p L$ might be discovered, as recently demonstrated for $h r p L$ of E. carotovora (Chatterjee et al. 2002), the present data suggest that phosphorylation of HrpY is a dominant factor in triggering the hrp regulon.

Sequence analysis of the HrpXY proteins suggests that, together, they constitute a two-component regulatory system. In general, such systems consist of pairs of partner proteins called sensors and response regulators (Hoch and Silhavy 1995). Sensors act as histidine protein kinases that can phosphorylate themselves and as phosphotransferases that can interact with and phosphorylate partner regulators. Therefore, the observation that a nonpolar $h r p X$ mutant remained fully virulent (Table 1) and did not affect the expression of the hrp regulatory cascade in planta through the phosphorylation of HrpY (Fig. 3) was unexpected. However, response regulators may receive input signals from different regulatory systems in a process termed "cross regulation" (Wanner 1992). Cross regulation may be an important form of global control that links response regulators of two-component regulatory systems to each other or to other general regulatory systems. One of the best examples of cross regulation is the phosphate (PHO) regulon of Escherichia coli, in which the $\mathrm{PhoB}$ regulator can be phosphorylated by two nonpartner sensor kinases in addition to PhoR, its own partner-sensor (Wanner 1990). The extent to which cross regulation occurs in vivo is not yet known. The dispensability of HrpX in E. herbicola pv. gypsophilae can be analyzed in the light of two hypotheses: i) the HrpX sensor is nonfunctional in phosphorylation of HrpY; and ii) the HrpX is functional under normal conditions but can be fully replaced by an alternative source for HrpY phosphorylation when HrpX is not expressed. At present, we cannot resolve between these two possibilities In contrast to E. herbicola pv. gypsophilae, nonpolar hrpX mutants of E. amylovora (Wei et al. 2000) and of P. stewartii (Merighi et al. 2001) caused only a reduced virulence. These results suggest that phosphorylation of HrpY can be carried out by alternative phosphoryltransferases that exist in these bacteria, in addition to HrpX.

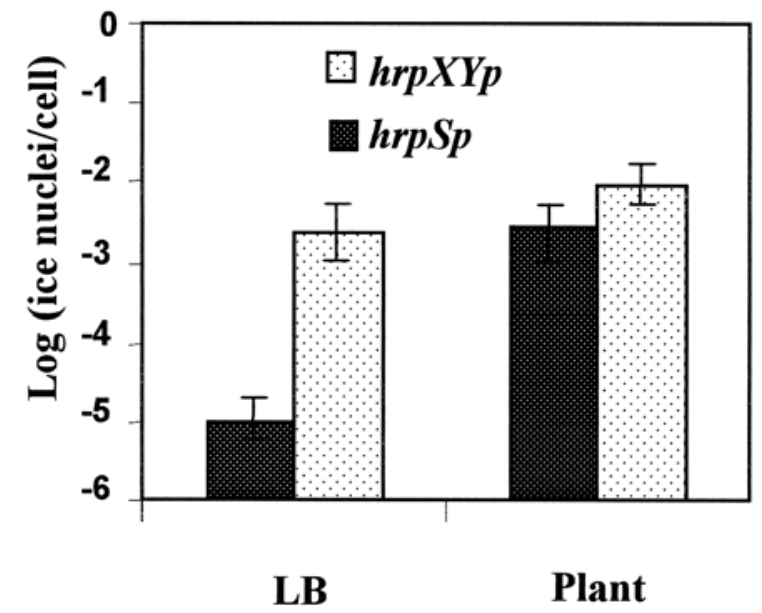

Fig. 5. Transcriptional activity of $h r p X Y$ and $h r p S$ promoters in bacteria grown under repressive and inductive conditions. Ehg824-1 was transformed with either pPROBE- $h r p X Y p$ or pPROBE- $h r p S p$. The transconjugants were grown either at $28^{\circ} \mathrm{C}$ for $24 \mathrm{~h}$ on LB agar or for $16 \mathrm{~h}$ in planta prior to determination of ice nucleation activity.
The overexpression of $h r p S$ by lac promoter under repressive conditions was characterized by concurrent stimulation of $h r p L, h r p X Y$, and $h r p S$ (Fig. 2). This puzzling result is contradictory to the linear cascade model (Fig. 7), since HrpS not only activates its upstream gene (i.e., hrpY) but also forms an autoregulatory loop, through which it self-activates. It might be speculated that due to absence of effective terminators between $h r p L, h r p X Y$, and $h r p S$ (Fig. 1), HrpS-driven transcription of $h r p L$ under repressive conditions proceeds into $h r p X Y$ and $h r p S$ and simultaneously stimulates their expression (Fig. 2). However, this phenomenon of a common transcript did not occur by lacp-hrpL fusion, suggesting a more complex explanation. A similar autoregulatory loop was observed with $P$. stewartii (Merighi et al. 2001; M. Merighi and D. L. Coplin, personal communication). Whether the autoregulatory loop represents an alternative mechanism for activating the Hrp regulon under repressive conditions when HrpY apparently cannot be phosphorylated or an in vitro artifact remains to be determined.

It is noteworthy that, with the exception of the overexpression experiment (Table 2), all the experiments performed in this study were carried out with bacteria grown in stems of gypsophila cuttings. Under these conditions the bacteria reside in the xylem vessels and the adjacent intercellular cavities (Valinsky et al. 2002) that constitute the apoplast, in which phytopathogenic bacteria grow and function. The gypsophila stems also exhibited the highest inductive conditions for the hrp regulatory cascade (Table 2 ). For the in vivo experiments, we took advantage of the inaZ ice nucleation reporter gene system. This system is particularly well adapted for assessing in situ gene expression by bacteria in their natural habitats (Loper and Lindow 1997) and enabled us to avoid the presence of artifacts caused by artificial conditions or a reporter system.

The ability to sense and rapidly respond to external stimuli enables phytopathogenic bacteria to colonize and attack their host plants. The regulatory process used in bacterial sensing and response commonly involves signal transduction and gene regulation mechanisms based upon two-component systems (Hoch and Silhavy 1995) that might also act in E. herbicola pv. gypsophilae. In the present study, we have characterized the last steps of the signal transduction pathway that activates the Hrp regulon in E. herbicola pv. gypsophilae. It appears that both transcriptional and posttranslational regulations are involved in activating the hrp regulatory cascade. However, mechanisms through which plant signals are perceived by the

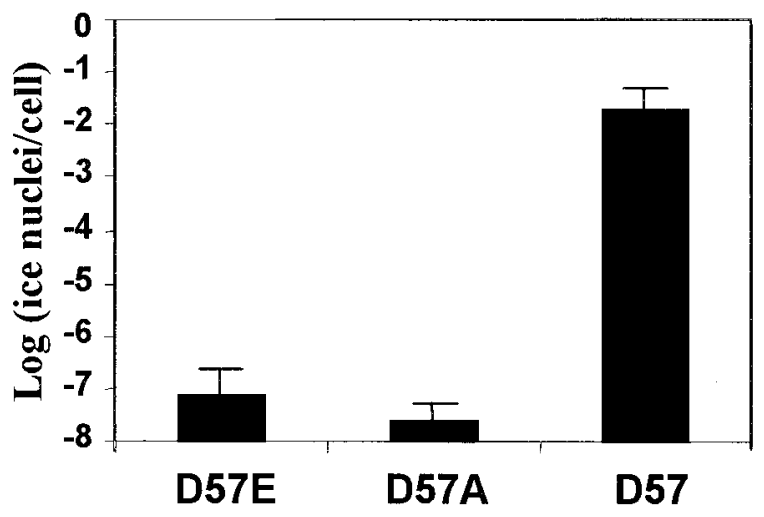

Fig. 6. The role of the conserved aspartate D57 in HrpY. Aspartate encoded by codon 57 of HrpY was converted into either alanine or glutamate by sitedirected mutagenesis. Double mutants EhgMxS $\mathrm{Tn}_{\mathrm{Tn}} / \mathrm{Y}-\mathrm{A} 57$ and $E h g \mathrm{MxS}_{\mathrm{Tn} 3} / \mathrm{Y}-$ E57, containing an inaZ reporter gene in $h r p S$ and codons encoding alanine (D57A) and glutamate (D57E) in $h r p Y$, respectively, were used to test the activation of $h r p S$ by HrpY. A single mutant, Ehg $\mathrm{MxS}_{\mathrm{Tn} 3}$, containing inaZ in $h r p S$ and aspartate (D57) was used as a control. Ice nucleation activity of $h r p S$ was determined in bacteria grown in gypsophila stems. 
pathogen and transduced to phosphorylate HrpY remain unresolved. Furthermore, it is quite feasible that the Hrp regulon might be affected by additional transcriptional and posttranscriptional effectors, some of which are controlled by global regulation systems (Chatterjee et al. 2002).

\section{MATERIALS AND METHODS}

Bacterial strains, plasmids, and growth conditions.

The bacterial strains, cosmids, and plasmids used in the present study are listed in Table 3. The wild-type strain E. herbicola pv. gypsophilae 824-1, which is resistant to rifampicin (Manulis et al. 1991), and its derivatives were used throughout. Bacteria were grown in either LB broth and agar or minimal A medium or minimal M-9 medium (Ausubel et al. 1995) with appropriate antibiotics at $28^{\circ} \mathrm{C}$ for E. herbicola pv. gypsophilae and at $37^{\circ} \mathrm{C}$ for Escherichia coli. Genetic manipulations were carried out in Escherichia coli strains DH5 $\alpha$ or HB101 (Table 3). Antibiotics were used in the following concentrations ( $\mu$ g per $\mathrm{ml})$ : ampicillin, 150; chloramphenicol $(\mathrm{Cm}), 20$; kanamycin $(\mathrm{Km}), 50$; rifampicin, 100; spectinomycin, 50; and tetracycline, 15.

\section{Pathogenicity and HR tests.}

Pathogenicity tests were performed on cuttings of Gypsophila paniculata cv. perfecta essentially as described by Valinsky and associates (1998). After removal of an approximately 2-mm section from the bottom of the stem, the cuttings were inoculated by dipping them into a bacterial suspension of $10^{8} \mathrm{CFU}$ per $\mathrm{ml}$ for $30 \mathrm{~min}$, after which they were placed in trays filled with vermiculite. The greenhouse temperature was maintained at 25 to $28^{\circ} \mathrm{C}$, and high humidity was generated by computer-controlled mist sprinklers (Lichter et al. 1995a). The hypersensitivity test was performed on tobacco leaves (Nicotiana tabacum L. cv. Hicks) as previously described (Nizan et al. 1997).

\section{Recombinant DNA techniques and DNA sequence analysis.}

DNA isolation, restriction enzyme digestions, agarose gel electrophoresis, subcloning, transformations, Southern blot analysis, and polymerase chain reaction (PCR) were performed according to standard procedures (Ausubel et al. 1995; Sambrook et al. 1989) or as recommended by the supplier. Isolation of plasmid DNA from E. herbicola pv. gypsophilae was performed as described previously (Lichter et al. 1995a). Primers were synthesized by Gibco-BRL (Glasgow, Scotland).

DNA fragments for sequencing were subcloned into pBluescript $\left(\mathrm{KS}^{+}\right)$and automated sequencing with Taq DNA polymerase was carried out in the Biological Services Laboratories of Tel-Aviv University. DNA and amino acid sequences were analyzed by GCG software package, version 7.3 (Genetics Computer Group, Madison, WI, U.S.A). Homology searches were done with BLAST algorithms (Altschul et al. 1997) (available online from the NCBI website). Conserved patterns in proteins were found with Scan-Prosite (Appel et al. 1994; available online).

\section{Construction of marker exchange mutant.}

Plasmid pMBN-H6.4 (Mor et al. 2001) containing the regulatory genes (Fig. 1) was used for mutagenesis by the transposon-reporter pTn3-Spice and mini-Tn10, as described elsewhere (De Lorenzo and Timmis 1994; Lindgren 1997). Insertional mutants (120) obtained by each transposon were randomly selected for further analysis. The locations of the Tn3Spice and mini-Tn 10 in each of the regulatory genes were initially determined in Escherichia coli strains SF800 and HB101 (Table 3), respectively, by mapping with multiple restriction enzymes and were confirmed by sequencing of selected mutated plasmids. Mutations by Tn3-Spice were chosen so that the transcriptional orientation of the ice nucleation reporter gene inaZ (Lindgren et al. 1989) would be aligned with the gene promoter. The mutated plasmids with either Tn3-Spice or mini-Tn 10 were then mobilized into E. herbicola pv. gypsophillae $824-1$ by triparental mating with pRK2073 or pRK2013 (Table 3) as a helper plasmid (Ditta et al. 1980). Plasmid curing was performed as previously described (Lichter et al. 1995b). This procedure yielded the following marker exchange mutants: $E h g \mathrm{MxL}_{\mathrm{Tn} 3} ; E h g \mathrm{MxS}_{\mathrm{Tn} 3}, \quad E h g \mathrm{MxX}_{\mathrm{Tn} 3}, \quad E h g \mathrm{MxL}_{\mathrm{Tn} 10}$, $E h g \mathrm{MxS}_{\mathrm{Tn} 10}$, and $E h g \mathrm{MxX} \mathrm{X}_{\mathrm{Tn} 10}$ (Table 3). Since no transposon insertion could be obtained in $h r p Y$ by the above procedure, a Km-resistance cassette obtained from pUC4K (Table 3) was introduced into $h r p Y$ as follows: two DNA fragments of 1.5 and $0.65 \mathrm{~kb}$ were synthesized with pairs of the primers $\mathrm{Ym}$ Pst1/XY-Hind and Ym-Pst2/XY-Bam, respectively (Table 4). The resulting DNA sequences were cloned into pLAFR3, and the $\mathrm{Km}$ cassette was inserted into the synthetic PstI site formed between the two DNA fragments. The latter mutation was marker exchanged into E. herbicola pv. gypsophilae to yield Ehg MxY $\mathrm{Km}_{\mathrm{m}}$ (Table 3).

In order to test the interaction among regulatory genes or between regulatory genes and other hrp genes, we constructed double mutants containing the inaZ reporter (introduced by $\mathrm{Tn} 3$-Spice) in one gene and a $\mathrm{Km}$ insertion in the other gene. To achieve this aim, each of the various mutants carrying a $\mathrm{Km}$ insertion was marker exchanged into a Tn3-Spice mutant to create a double mutant. Thus Ehg $\mathrm{MxL}_{\mathrm{Tn} 10}, E h g \mathrm{MxS}_{\mathrm{Tn} 10}$, $E h g \mathrm{MxX}_{\mathrm{Tn} 10}$, and $E h g \mathrm{MxY} \mathrm{Km}_{\mathrm{Km}}$ (Table 3) were marker exchanged individually into EhgMx14 (Tn3-Spice in $h r p N$ ) (Mor

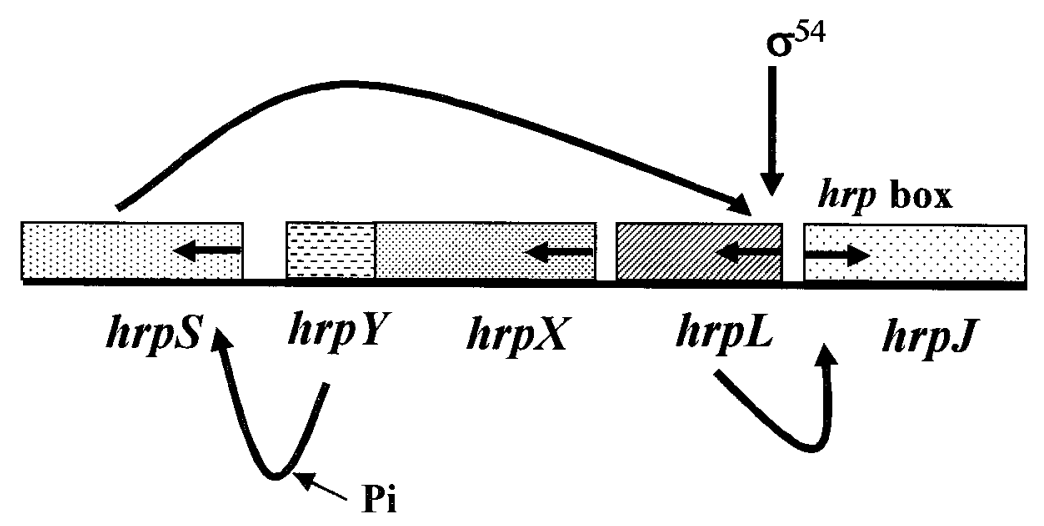

Fig. 7. A proposed model for hrp regulatory cascade in Erwinia herbicola pv. gypsophilae. HrpY is phosphorylated in planta by an as yet unresolved mechanism. The phosphorylated HrpY then stimulates $h r p S$ expression and HrpS, together with $\sigma 54$, activates $h r p L$. Finally, HrpL activates promoters containing $h r p$ boxes, which characterize all the genes controlled by the hrp regulon. hrpX is dispensable for pathogenicity. 
et al. 2001) and EhgMx33 (Tn3-Spice in hrpJ) (Nizan et al. 1997), respectively, to obtain the double mutants $E h g \mathrm{MxN}_{\text {inaz }} / L_{\mathrm{Km}}$, $E h g \mathrm{MxN}_{\text {inaz }} / \mathrm{S}_{\mathrm{Km}}, E h g \mathrm{MxN}_{\text {inaZ }} / \mathrm{Y}_{\mathrm{Km}}$, and $\operatorname{EhgMxN}_{\text {inaz }} / \mathrm{X}_{\mathrm{Km}}$, as well as $E h g \mathrm{MxJ}_{\text {inaz }} / \mathrm{L}_{\mathrm{Km}}, \quad E h g \mathrm{MxJ}_{\mathrm{inaZ}} / \mathrm{S}_{\mathrm{Km}}, \quad E h g \mathrm{MxJ}_{\text {inaz }} / \mathrm{Y}_{\mathrm{Km}}$, and EhgMxJ $\mathrm{ina}_{\mathrm{in}} / \mathrm{X}_{\mathrm{Km}}$. Similarly, the $\mathrm{Km}$ mutations of the four regulatory genes were marker exchanged into each of the Tn3Spice mutants in $h r p L, h r p S$, and $h r p X$ (but not into identical genes) to obtain the respective double mutants listed in Table 3.
Site-directed mutagenesis of codon D57 in hrpY.

The role of the conserved aspartate residue at position 57 (D57) in hrpY was evaluated by its substitution into either alanine (A57) or glutamate (E57). To achieve this aim, primers DtoA-SDM and DtoE-SDM (Table 4) in which the codon D57 (GAT) was modified to A57 (GCT) and E57 (GAG), respectively, were synthesized and phosphorylated with polynucleotide kinase (BioLabs Inc., Beverley, MA, U.S.A.). A 457-bp

Table 3. Bacterial strains, cosmids, and plasmids used in this study

\begin{tabular}{|c|c|c|}
\hline Strain/plasmid & Relevant characteristics & Reference or source \\
\hline \multicolumn{3}{|l|}{ Escherichia coli } \\
\hline DH5 $\alpha$ & $\begin{array}{l}\mathrm{F}-, \notin 80 \mathrm{dlacZ} \Delta \mathrm{M} 15, \Delta) \operatorname{lac} Z Y \mathrm{~A}-\operatorname{argF}), \mathrm{U} 169, \operatorname{deoR}, \operatorname{Rec} \mathrm{A} 1, \operatorname{end} \mathrm{A} 1, h s d R 17) \mathrm{r}_{\mathrm{k}-}, \mathrm{m}_{\mathrm{k}+}(\sup E 44, \lambda,- \\
\text { thi,1- gyrA96, relA1 }\end{array}$ & Hanahan 1983 \\
\hline HB101 & gal $\mathrm{U}$, galK, $\lambda{ }^{-} r p s \mathrm{~L}$, end $\mathrm{A} 1, n u p \mathrm{G}, \sup \mathrm{E} 44, m r c \mathrm{~B}, m r r, h s d \mathrm{~S} 20, r e c \mathrm{~A} 1$ & Gibco BRL \\
\hline SF800 & $\mathrm{Nal}^{-}$, polA & Lindgren et al. 1989 \\
\hline \multicolumn{3}{|l|}{ Erwinia herbicola } \\
\hline Ehg824-1 & Rif $^{\mathrm{r}}$ Wild-type pathogenic strain on gypsophila, serotype I & Manulis et al. 1991 \\
\hline EhgMx14 & $\operatorname{Rif}^{\mathrm{r}} \mathrm{Sm}^{\mathrm{r}} \mathrm{Spec}^{\mathrm{r}}$ Marker-exchange mutant of Tn3-Spice in $h r p N$ & Nizan et al. 1997 \\
\hline EhgMx33 & $\operatorname{Rif}^{\mathrm{r}} \mathrm{Sm}^{\mathrm{r}} \mathrm{Spec}^{\mathrm{r}}$ Marker-exchange mutant of Tn3- Spice in $h r p J$ operon & Nizan et al. 1997 \\
\hline Ehg $\mathrm{MxL}_{\mathrm{Tn} 3}$ & $\operatorname{Rif}^{\mathrm{r}} \mathrm{Sm}^{\mathrm{r}} \mathrm{Spec}^{\mathrm{r}}$ Marker-exchange mutant of Tn3-Spice in $h r p L$ & This study \\
\hline Ehg $\mathrm{MxS}_{\mathrm{Tn} 3}$ & $\operatorname{Rif}^{\mathrm{r}} \mathrm{Sm}^{\mathrm{r}} \mathrm{Spec}^{\mathrm{r}}$ Marker-exchange mutant of Tn3-Spice in $h r p S$ & This study \\
\hline Ehg MxX $\mathrm{X}_{\mathrm{Tn} 3}$ & $\operatorname{Rif}^{r} \mathrm{Sm}^{\mathrm{r}} \mathrm{Spec}{ }^{\mathrm{r}}$ Marker-exchange mutant of Tn3-Spice in $h r p X$ & This study \\
\hline Ehg MxL $\mathrm{L}_{\mathrm{Tn} 10}$ & $\operatorname{Rif}^{\mathrm{r}} \mathrm{Km}^{\mathrm{r}}$ Marker-exchange mutant of mini-Tn 10 in $h r p L$ & This study \\
\hline Ehg MxS $\mathrm{S}_{\mathrm{Tn} 10}$ & $\operatorname{Rif}^{\mathrm{r}} \mathrm{Km}^{\mathrm{r}}$ Marker-exchange mutant of mini-Tn10 in hrpS & This study \\
\hline EhgMxX & $\operatorname{Rif}^{\mathrm{r}} \mathrm{Km}^{\mathrm{r}}$ Marker-exchange mutant of mini-Tn 10 in $h r p X$ & This study \\
\hline Ehg Mx $\mathrm{Y}_{\mathrm{km}}$ & $\operatorname{Rif}^{\mathrm{r}} \mathrm{Km}^{\mathrm{r}}$ Marker-exchange mutant of km cassette in $h r p Y$ & This study \\
\hline$E h g \mathrm{MxN}_{\mathrm{inaZ}} / \mathrm{L}_{\mathrm{km}}$ & $\operatorname{Rif}^{\mathrm{r}} \mathrm{Sm}^{\mathrm{r}} \mathrm{Spec}^{\mathrm{r}} \mathrm{Km}^{\mathrm{r}}$ Double mutant in $h r p N$ and $h r p L$ & This study \\
\hline Ehg MxN $\mathrm{N}_{\text {inaz }} / \mathrm{S}_{\mathrm{Km}}$ & $\operatorname{Rif}^{\mathrm{r}} \mathrm{Sm}^{\mathrm{r}} \mathrm{Spec}{ }^{\mathrm{r}} \mathrm{Km}^{\mathrm{r}}$ Double mutant in $h r p N$ and $h r p S$ & This study \\
\hline EhgMxNinaz/Y $\mathrm{Y}_{\mathrm{Km}}$ & $\operatorname{Rif}^{\mathrm{r}} \mathrm{Sm}^{\mathrm{r}} \mathrm{Spec}^{\mathrm{r}} \mathrm{Km}^{\mathrm{r}}$ Double mutant in $h r p N$ and $h r p Y$ & This study \\
\hline EhgMxN $\mathrm{N}_{\text {inaz }} / \mathrm{X}_{\mathrm{km}}$ & $\operatorname{Rif}^{\mathrm{r}} \mathrm{Sm}^{\mathrm{r}} \mathrm{Spec}^{\mathrm{r}} \mathrm{Km}^{\mathrm{r}}$ Double mutant in $h r p N$ and $h r p X$ & This study \\
\hline$E h g \mathrm{MxJ}_{\text {inaz }} / \mathrm{L}_{\mathrm{Km}}$ & $\operatorname{Rif}^{\mathrm{r}} \mathrm{Sm}^{\mathrm{r}} \mathrm{Spec}^{\mathrm{r}} \mathrm{Km}^{\mathrm{r}}$ Double mutant in $h r p J$ and $h r p L$ & This study \\
\hline$E h g \mathrm{MxJ}_{\mathrm{inaz}} / \mathrm{S}_{\mathrm{Km}}$ & $\operatorname{Rif}^{\mathrm{r}} \mathrm{Sm}^{\mathrm{r}} \mathrm{Spec}^{\mathrm{r}} \mathrm{Km}^{\mathrm{r}}$ Double mutant in $h r p J$ and $h r p S$ & This study \\
\hline EhgMxJinaz/ $\mathrm{Y}_{\mathrm{Km}}$ & $\operatorname{Rif}^{\mathrm{r}} \mathrm{Sm}^{\mathrm{r}} \mathrm{Spec}^{\mathrm{r}} \mathrm{Km}^{\mathrm{r}}$ Double mutant in $h r p J$ and $h r p Y$ & This study \\
\hline Ehg $\mathrm{MxJ}_{\mathrm{inaz}} / \mathrm{X}_{\mathrm{Km}}$ & $\operatorname{Rif}^{\mathrm{r}} \mathrm{Sm}^{\mathrm{r}} \mathrm{Spec}^{\mathrm{r}} \mathrm{Km}^{\mathrm{r}}$ Double mutant in $h r p J$ and $h r p X$ & This study \\
\hline Ehg MxL $\mathrm{L}_{\text {inaz }} / \mathrm{S}_{\mathrm{Km}}$ & $\operatorname{Rif}^{\mathrm{r}} \mathrm{Sm}^{\mathrm{r}} \mathrm{Spec}^{\mathrm{r}} \mathrm{Km}^{\mathrm{r}}$ Double mutant in $h r p L$ and $h r p \mathrm{~S}$ & This study \\
\hline EhgMxLinaz/Y $\mathrm{Km}_{\mathrm{m}}$ & $\operatorname{Rif}^{\mathrm{r}} \mathrm{Sm}^{\mathrm{r}} \mathrm{Spec}^{\mathrm{r}} \mathrm{Km}^{\mathrm{r}}$ Double mutant in $h r p L$ and $h r p Y$ & This study \\
\hline Ehg MxL $\mathrm{L}_{\mathrm{ina}} / \mathrm{X}_{\mathrm{km}}$ & $\operatorname{Rif}^{\mathrm{r}} \mathrm{Sm}^{\mathrm{r}} \mathrm{Spec}^{\mathrm{r}} \mathrm{Km}^{\mathrm{r}}$ Double mutant in $h r p L$ and $h r p X$ & This study \\
\hline Ehg MxS $\mathrm{SnaZ}_{\mathrm{inz}} / \mathrm{L}_{\mathrm{km}}$ & $\operatorname{Rif}^{\mathrm{r}} \mathrm{Sm}^{\mathrm{r}} \mathrm{Spec}^{\mathrm{r}} \mathrm{Km}^{\mathrm{r}}$ Double mutant in $h r p S$ and $h r p L$ & This study \\
\hline EhgMxS $\mathrm{S}_{\mathrm{inaz}} / \mathrm{Y}_{\mathrm{Km}}$ & $\operatorname{Rif}^{\mathrm{r}} \mathrm{Sm}^{\mathrm{r}} \mathrm{Spec}^{\mathrm{r}} \mathrm{Km}^{\mathrm{r}}$ Double mutant in $h r p S$ and $h r p Y$ & This study \\
\hline EhgMxSinaz/X $\mathrm{X}_{\mathrm{Km}}$ & $\operatorname{Rif}^{\mathrm{r}} \mathrm{Sm}^{\mathrm{r}} \mathrm{Spec}^{\mathrm{r}} \mathrm{Km}^{\mathrm{r}}$ Double mutant in $h r p S$ and $h r p X$ & This study \\
\hline Ehg $\mathrm{MxX}_{\mathrm{inaZ}} / \mathrm{L}_{\mathrm{km}}$ & $\operatorname{Rif}^{\mathrm{r}} \mathrm{Sm}^{\mathrm{r}} \mathrm{Spec}^{\mathrm{r}} \mathrm{Km}^{\mathrm{r}}$ Double mutant in $h r p X$ and $h r p L$ & This study \\
\hline Ehg $\mathrm{MxX} \mathrm{inaz}_{\mathrm{K}} / \mathrm{S}_{\mathrm{Km}}$ & $\operatorname{Rif}^{\mathrm{r}} \mathrm{Sm}^{\mathrm{r}} \mathrm{Spec}^{\mathrm{r}} \mathrm{Km}^{\mathrm{r}}$ Double mutant in $h r p X$ and $h r p S$ & This study \\
\hline $\begin{array}{l}\text { EhgMxS } \\
\text { A57 }\end{array}$ & $\operatorname{Rif}^{r} \mathrm{Sm}^{\mathrm{r}} \mathrm{Spec}^{\mathrm{r}}$ The aspartate residue (D57) was replaced by alanine & This study \\
\hline EhgMxS $\mathrm{Tn} 3_{\mathrm{T}} / \mathrm{Y}-\mathrm{E} 57$ & $\operatorname{Rif}^{\mathrm{r}} \mathrm{Sm}^{\mathrm{r}} \mathrm{Spec}^{\mathrm{r}}$ The aspartate residue (D57) was replaced by glutamate & This study \\
\hline \multicolumn{3}{|c|}{ 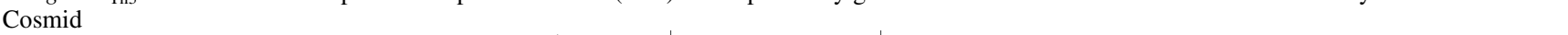 } \\
\hline pLAFR3 & $\mathrm{Tc}^{\mathrm{r}}$, Broad range vector $\mathrm{IncP}, 1-$ rix RK2, ${ }^{+}$lacZA , Tra , Mob, ${ }^{+}$cos. & Staskawicz et al. 1987 \\
\hline \multicolumn{3}{|c|}{ 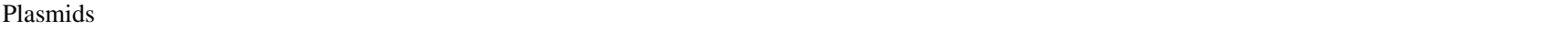 } \\
\hline Pbluescript (pBS) & $\mathrm{Amp}^{\mathrm{r}}$ subcloning and sequencing vector $\mathrm{KS}^{+}$ & Stratagen \\
\hline pVSP61 & $\mathrm{Km}^{\mathrm{r}}, \mathrm{pVS} 1$ replicon & \\
\hline pRK2073 & $\operatorname{Spec}^{\mathrm{r}} \mathrm{Sm}^{\mathrm{r}}$, a helper plasmid for triparental matings & Ditta et al. 1980 \\
\hline pRK2013 & $\mathrm{Km}^{\mathrm{r}}$ a helper plasmid for triparental mating & Ditta et al. 1980 \\
\hline pTn3-Spice & $\mathrm{Amp}^{\mathrm{r}} \mathrm{Spec}^{\mathrm{r}} \mathrm{Sm}^{\mathrm{r}}$, clone containing the InaZ reporter gene and the $\Omega$ cassette in $\operatorname{Tn} 3$ & Lindgren et al. 1989 \\
\hline Mini-Tn10 & $\mathrm{Km}^{\mathrm{r}}$, IS10R transposase gene expressed from tacp and the $\mathrm{Tn} 10$ inverted repeat ends. & De Lorenzo and Timmis 1994 \\
\hline pSShe & $\mathrm{Cm}^{\mathrm{r}}$ tnpA, $\mathrm{pACYC} 184$ replicon. & Lindgren et al. 1989 \\
\hline pUC4K & $\mathrm{Km}^{\mathrm{r}} \mathrm{Amp} \mathrm{r}^{\mathrm{r}}$, Kanamycin resistance cassette used for gene disruption. & Pharmacia \\
\hline pPROBE-GI & $\begin{array}{l}\mathrm{Gm}^{\mathrm{r}} \mathrm{pVS} 1 \text { replicon, Broad host range promoter probe vector. Reporter gene inaZ, multi cloning } \\
\text { site orientation HindIII } \rightarrow \text { EcoRI }\end{array}$ & Miller et al. 2000 \\
\hline pPROBE-GI' & $\begin{array}{l}\mathrm{Gm}^{\mathrm{r}} \text {, pVS1 replicon, Broad host range promoter probe vector. Reporter gene inaZ, multi cloning } \\
\text { site orientation EcoRI } \rightarrow \text { HindIII }\end{array}$ & Miller et al. 2000 \\
\hline pMBN6.4H & $\mathrm{Tc}^{\mathrm{r}}, \mathrm{a} 6.4-\mathrm{kb}$ HindIII fragment from pLA352 cloned into pLAFR3 & \\
\hline pVSPhrpS & $\mathrm{Km}^{\mathrm{r}}, h r p S$ gene cloned into pVSP61 under lac promoter & This study \\
\hline pVSPhrpL & $\mathrm{Km}^{\mathrm{r}}$, hrpL gene cloned into pVSP61 under lac promoter & This study \\
\hline pVSPhrpY & $\mathrm{Km}^{\mathrm{r}}, h r p Y$ gene cloned into pVSP61 under lac promoter & This study \\
\hline pPROBE- $h r p S p$ & $\mathrm{Gm}^{\mathrm{r}}, \mathrm{A} 440-\mathrm{kb}$ PCR fragment from the promoter region of $h r p S$ cloned into pPROBE-GI & This study \\
\hline pPROBE- $h r p L p$ & $\mathrm{Gm}^{\mathrm{r}}$, A 510-kb HincII-ClaI fragment from the promoter region of $h r p L$ cloned into pPROBE-GI & This study \\
\hline pPROBE- $h r p X Y p$ & $\begin{array}{l}\mathrm{Gm}^{\mathrm{r}} \text {, A 300-kb EcoRI-EcoRV fragment from the promoter region of } h r p X Y \text { cloned into } \\
\text { pPROBE-GI }\end{array}$ & This study \\
\hline pPROBE- $h r p J p$ & $\mathrm{Gm}^{\mathrm{r}}$, A 510-kb HincII-ClaI fragment from the promoter region of $h r p L$ cloned into pPROBE-GI' & This study \\
\hline pVSP-D57E & $\begin{array}{l}\mathrm{Km}^{\mathrm{r}} \mathrm{Cm}^{\mathrm{r}} \text {, site directed mutation of } h r p Y \text { by changing the aspartate } 57 \text { to glutamic acid, cloned } \\
\text { into pVSP61 }\end{array}$ & This study \\
\hline pVSP-D57A & $\begin{array}{l}\mathrm{Km}^{\mathrm{r}} \mathrm{Cm}^{\mathrm{r}} \text {, site directed mutation of } h r p Y \text { by changing the aspartate } 57 \text { to alanine, cloned into } \\
\text { pVSP61 }\end{array}$ & This study \\
\hline
\end{tabular}


DNA fragment was amplified by PCR with primers SDM2 and XY-Bam (Table 4), and two 180-bp fragments were amplified by the primer pairs Y-Hind/DtoA-SDM and Y-Hind/DtoESDM ( Table 4). Each of the two 180-bp fragments was ligated to the 457-bp fragment, cut with HindIII and BamHI, and cloned into pBluescript. The inserted fragments were sequenced and clones in which the expected base pair substitution was confirmed were subcloned into pVSP61 to yield pVSP-D57A and pVSP-D57E. The gene encoding for acetyl transferase was then inserted into the former and latter plasmids to render them resistant to chloramphenicol. This was achieved by PCR amplification with primers $\mathrm{Cm}$-start and $\mathrm{Cm}$ end (Table 4) and with plasmid pSShe (Table 3) as a template. The resultant DNA fragment was cloned into pVSP-D57A or pVSP-D57E after digestion with EcoRI and filling of the cohesive termini of the restriction sites with Klenow enzyme to form blunt ends. The Cm-resistant pVSP-D57A or pVSP-D57E was then marker exchanged into $E h g \mathrm{MxS}_{\mathrm{Tn} 3}$ (harboring inaZ in $h r p S)$ to obtain the double mutants $E h g \mathrm{MxS}_{\mathrm{Tn} 3} / \mathrm{Y}-\mathrm{A} 57$ and Ehg $\mathrm{MxS}_{\mathrm{Tn} 3} / \mathrm{Y}-\mathrm{E} 57$.

\section{Construction of lacp-hrpY, lacp-hrpS, lacp-hrpL,} and promoters of $\boldsymbol{h r p}$ genes in reporter plasmids.

For the complementation and overexpression experiments, the $h r p Y, h r p X$, and $h r p L$ ORFs, including their ribosomal binding sites, were amplified by PCR and cloned into pVSP61 under its lac promoter to yield pVSPhrpY, pVSPhrpS, and pVSPhrpL (Table 3). To facilitate cloning into pVSP61, a HindIII restriction site was added to the primers designed for synthesis of the ORF N-terminus, whereas either an EcoRI or a BamHI restriction site was added to primers designed for synthesis of the ORF C-terminus. Thus, the primer pairs YHind/XY-Bam, S-Hind/S-EcoRI, and L-Hind/L-EcoRI (Table 3) were used for synthesis of $h r p Y, h r p S$, and $h r p L$, respectively. The plasmid pMBN-6.4H was used as a template for the amplification reactions.

The plasmids pPROBE-GI and pPROBE-GI' were employed for testing the transcriptional activity of isolated promoters (Miller et al. 2000). Each plasmid contained a promoter-probe cassette that consisted of multicloning sites upstream to the ice-nucleation reporter gene inaZ. The cassette was bound by transcriptional terminators to permit the insertion of strong promoters and to insulate the cassette from external transcription, enabling the detection of weak or moderate promoters. The $h r p X Y$ promoter was obtained by digesting pMBN-6.4H with EcoRI and EcoRV. A 300-bp DNA fragment containing the promoter (Fig. 1) was then cloned into pPROBE-GI that was predigested with SmaI and EcoRI to yield pPROBE-hrpXYp (Table 3). The hrpS promoter was amplified by PCR with the primers PhrpS-A and PhrpS-B (Table 4) containing HindIII and BamHI restriction sites, respectively, to synthesize a 440-bp DNA fragment. This fragment was cloned into pPROBE-GI to yield pPROBE- $h r p S p$ (Table 3). For cloning the $h r p L$ and $h r p J$ (the first gene of the hrpJ operon) (Mor et al. 2001) promoters, advantage was taken of the fact that these two genes are adjacent to each other but transcribe in opposite orientations (Fig. 1). A 510-bp DNA fragment containing both promoters was obtained by cutting pMBN-6.4H with HincII and ClaI and cloning it into pBluescript $\left(\mathrm{KS}^{+}\right)$. This fragment was then recovered by cutting the pBluescript with HincII and EcoRI and was cloned into pPROBE-GI to yield pPROBE-hrpLp and into pPROBE-GI' to yield pPROBE-hrpJp (Table 3). The locations of the promoters on pMBN-6.4H are illustrated in Figure 1. Each of the above-mentioned plasmids was then mobilized into E. herbicola pv. gypsophilae mutants harboring a $\mathrm{Km}^{\mathrm{r}}$ mutation in different regulatory genes to form transconjugants.

\section{Measurements of reporter gene activity.}

The ice nucleation reporter gene inaZ (Loper and Lindow 1997) was used to generate transcriptional fusions with tested promoters. The promoters drive the synthesis of InaZ protein that creates the nucleus around which ice is formed. The assay was prepared by dilution of bacterial suspensions and sampling of drops on the surface of cooled aluminum foils. The number of drops that freeze at a given dilution was calculated as $-\log$ (ice nuclei per cell) according to Loper and Lindow (1997). Significant differences in promoter activity are practically defined as being equal to or larger than 10-fold dilution or $1 \log$ (ice nuclei per cell).

Determination of ice nucleation activity was carried out according to Lindgren and associates (1989). Cells of different mutants and transconjugants of E. herbicola pv. gypsophilae were grown at $28^{\circ} \mathrm{C}$ on $\mathrm{LB}$ agar plates for $24 \mathrm{~h}$ or on minimal $\mathrm{A}$ or minimal M-9 agar plates for $48 \mathrm{~h}$. They were then suspended in $0.1 \mathrm{M} \mathrm{Na}$ phosphate buffer, $\mathrm{pH} 7$, brought to a concentration of $10^{9}$ cells per $\mathrm{ml}$ and, following serial 10 -fold dilutions, were subjected to ice nucleation assay at $-7^{\circ} \mathrm{C}$. Measurements of ice nucleation activity in inoculated stems was carried out with gypsophila (var. perfecta) cuttings. A bacterial suspension containing $10^{9}$ cells per ml was freshly prepared from an overnight growth in LB agar plates in phosphate buffer enriched with $0.1 \%$ bactopeptone. After removal of approximately $2 \mathrm{~mm}$ from the bottoms of the stems, the cuttings were placed in $15-\mathrm{ml}$ beakers (three cuttings per beaker) containing the bacterial suspension and were incubated under humid conditions in a growth chamber at $25^{\circ} \mathrm{C}$. After $16 \mathrm{~h}$, three cuttings per replication (three replications per treatment) were collected and a 5 to $8-\mathrm{mm}$ segment was excised from the bottom of each cutting and washed thoroughly

Table 4. Primers used in this study

\begin{tabular}{|c|c|c|c|}
\hline Primer & Sequence & Source & Restriction site added \\
\hline Ym-Pst2 & 5'-CACCTGCAGACGTTCGTCCAGCGAG-3' & pMBN6.4H & Pst $\mathrm{I}$ \\
\hline Ym-Pst1 & 5'-GGTCTGCAGCGAAGCGGGAAATGGTAC-3' & pMBN6.4H & Pst $\mathrm{I}$ \\
\hline Cm-start & 5'-GGTGTCGACGTAAGAGGTTCCAACTTTC-3' & pSShe & HincII \\
\hline Cm-end & 5'-CGCGTTAACTTAGCGCCCGCCCTGCC-3' & pSShe & HincII \\
\hline $\mathrm{XY}-$ Hind & 5'-CGTAAGCTTTAAGGAGATGAGATGCAG-3' & pMBN6.4H & HindIII \\
\hline Y-Hind & 5'-AATAAGCTTGCAGGTTTGGGATAATATCATG-3' & pMBN6.4H & HindIII \\
\hline S-Hind & 5'-GGGAAGCTTATGAGCATCAAGAAGAATAG-3' & pMBN6.4H & HindIII \\
\hline L-Hind & 5'-GCCAAGCTTTCACCATTAAGCCGAACG-3' & pMBN6.4H & HindIII \\
\hline $\mathrm{S}-E c o \mathrm{RI}$ & 5'-GGAGAATTCCGGATCGGGCTGACAAGG-3' & pMBN6.4H & EcoRI \\
\hline $\mathrm{L}-E c o \mathrm{RI}$ & 5'-GCAGAATTCCAGGATGATATTGAGAAGTGC-3' & pMBN6.4H & EcoRI \\
\hline XY-Bam & 5'-GAGGGATCCTAGGAAATTAAATGGTGAC-3' & pMBN6.4H & BamHI \\
\hline $\mathrm{PhrpS}$-H & 5'-GCAAAGCTTGTCAAATACGCGATAAGTCAC-3' & pMBN6.4H & HindIII \\
\hline PhrpS-B & 5'-ACTGGATCCGATGCTCATAAGAAGTTACCC-3' & pMBN6.4H & BamHI \\
\hline DtoA-SDM & 5'-TAGCTAACAGCAATAAATCGACCCG-3' & pMBN6.4H & \\
\hline DtoE-SDM & $5^{\prime}$-TCTCTAACAGCAATAAAATCGACCC-3' & pMBN6.4H & \\
\hline SDM-2 & $5^{\prime}$-TGTGCATGCCCGGATTAAGC-3' & pMBN6.4H & \\
\hline
\end{tabular}


with sterile distilled water. The stem segments were ground with a pestle within a small polyethylene bag, and $1 \mathrm{ml}$ of phosphate buffer was added to complete the tissue maceration. The resulting extract was subjected to a serial 10-fold dilution and was used for determination of ice nucleation activity and numbers of colony forming units by plating on LB agar containing appropriate antibiotics.

\section{ACKNOWLEDGMENTS}

This study was supported by research grant US-3265-01 from BARD, the U.S.-Israel Binational Agricultural Research and Development Fund, the DFG program for Trilateral Cooperation between Israel, Palestine, and Germany (grant no. EI 1440/11-1), and The Israel Academy of Sciences and Humanities (grant no. 578-01).

\section{LITERATURE CITED}

Aldon, D., Brito, B., Boucher, C., and Genin, S. 2000. A bacterial sensor of plant cell contact controls the transcriptional induction of Ralstonia solanacearum pathogenicity genes. EMBO (Eur. Mol. Biol. Organ.) J. 19:2304-2314.

Altschul, S. F., Madden, T. L., Schaffer, A. A., Zhang, J., Zhang, Z., Miller, W., and Lipman, D. L. 1997. Gapped BLAST and PSI BLAST: A new generation of protein database search programs. Nucleic Acids Res. 25:3389-3402.

Appel, R. D., Bairoch, A., and Hochstrasser, D. F. 1994. A new generation of information retrieval tools for biologists: The example of the ExPASy WWW server. Trends Biochem. Sci. 19:258-260.

Ausubel, F. M., Brent, R., Kingston, R. E., Moore, D. D., Seidman, J. G., Smith, J. A., and Struhl, K., eds. 1995. Current Protocols in Molecular Biology. John Wiley \& Sons, Inc., New York.

Bogdanove, A. J., Beer, S. V., Bonas, U., Boucher, C. A., Collmer, A., Coplin, D. L., Cornelis, G. R., Hunang, H. C., Hutcheson, S. W., Panopoulos, N. J., and Van-Gijsegem, F. 1996. Unified nomenclature for broadly conserved hrp genes of phytopathogenic bacteria. Mol. Microbiol. 20:681-683.

Bonas, U. 1994. hrp genes of phytopathogenic bacteria. Curr. Top. Microbiol. immunol. 192:79-98.

Brito, B., Aldon, D., Barberis, P., Boucher, C., and Genin, S. 2002. A signal transfer system through three compartments transduces the plant cell contact-dependent signal controlling Ralstonia solanacearum hrp genes. Mol. Plant-Microbe Interact. 15:109-119.

Burr, T. J., Katz, B. H., Abawi, G. S., and Crosier, D. C. 1991. Comparison of tumorigenic strains of Erwinia herbicola isolated from table beet with E. h. gypsophilae. Plant Dis. 75:855-858.

Chatterjee, A., Cul, Y., and Chatterjee, A. K. 2002. Regulation of Erwinia carotovora $h r p L_{\mathrm{Ecc}}\left(\operatorname{sigma}-L_{\mathrm{Ecc}}\right)$, which encodes an extracytoplasmic function subfamily of sigma factor required for expression of HRP regulon. Mol. Plant-Microbe Interact. 15:971-980.

Clark, E., Manulis, S., Ophir, Y., Barash, I., and Gafni, Y. 1993. Cloning and characterization of iaaM and iaaH from Erwinia herbicola pathovar gypsophilae. Phytopathology 83:234-240.

Cooksey, D. A. 1986. Galls of Gypsophila paniculata caused by Erwinia herbicola. Plant Dis. 70:464-468.

De Lorenzo, V., and Timmis, K. N. 1994. Analysis and construction of stable phenotypes in gram-negative bacteria with Tn5- and Tn10- derived minitransposons. Methods Enzymol. 235:386-405.

DeYoung, R. M., Copeman, R. J., and Hunt, R. S. 1998. Two strains in the genus Erwinia causes galls on Douglas-fir in southwestern British Columbia. Can. J. Plant Pathol. 20:194-200.

Ditta, G., Stanfield, S., Corbin, D., and Helinsky, D. R. 1980. Broad host range DNA cloning system for gram-negative bacteria: Construction of a gene bank of Rhizobium meliloti. Proc. Natl. Acad. Sci. U.S.A. 77:7343-7351.

Ezra, D., Barash, I., Valinsky, L., and Manulis, S. 2000. The dual function in virulence and host range restriction of a gene isolated from the pPATH $_{\text {Ehg }}$ plasmid of Erwinia herbicola pv. gypsophilae. Mol. PlantMicrobe Interact. 13:683-692.

Frederick, R. D., Majerczak, D. R., and Coplin, D. L. 1993. Erwinia stewartii WtsA, a positive regulator of pathogenicity gene expression, is homologous to Pseudomonas syringeae pv. phaseolicola HrpS. Mol. Microbiol. 9:477-485.

Galan, J. E., and Collmer, A. 1999. Type III secretion machines: Bacterial devices for protein delivery into host cells. Science 284:1322-1328.

Gavini, F., Mergaret, J., Beji, A., Mielcarek, C., Izard, D., Kersters, K., and De Ley, J. 1989. Transfer of Enterobacter agglomerans
(Beijerinck 1888) Ewing and Fife 1972 to Pantoea gen. nov. as Pantoea agglomerans comb. nov. and description of Pantoea dispersa sp. nov. Int. J. Syst. Bacteriol. 39:337-345.

Genin, S., and Boucher, C. 2002. Ralstonia solanacearum: Secrets of a major pathogen unveiled by analysis of its genome. Mol. Plant Pathol. 3:11-118.

Genin, S., Gough, C. L., Zischek, C., and Boucher, C. I. 1992. Evidence that the $h r p B$ gene encodes a positive regulator of pathogenicity genes from Pseudomonas solanacearum. Mol. Microbiol. 6:3065-3076.

Grimm, C., Aufsatz, W., and Panopoulos, N. J. 1995. The hrpRS locus of Pseudomonas syringae pv. phaseolicola constitutes a complex regulatory unit. Mol. Microbiol. 15:155-165.

Guo, M., Manulis, S., Mor, H., and Barash, I. 2002. The presence of diverse IS elements and an $a v r P p h D$ homologue that acts as a virulence factor on the pathogenicity plasmid of Erwinia herbicola pv. gypsophilae. Mol. Plant-Microbe Interact. 15:709-716.

Henikoff, S., Wallace, J. C., and Brown, J. P. 1990. Finding protein similarities with nucleotide sequence databases. Methods Enzymol. 183:111-132.

Hoch, J. A., and Silhavy, T. J. 1995. Two-component signal transduction. in: . American Society of Microbiology Press, Washington, DC.

Huang, J., Carney, B., Denny, T., Weissinger, A., and Schell, M. 1995. A complex network regulates expression of eps and other virulence genes of Pseudomonas solanacearum. J. Bacteriol. 177:1259-1267.

Hutcheson, S. W., Bretz, J., Sussan, T., Jin, S., and Pak, K. 2001. Enhancer-binding protein HrpR and HrpS interact to regulate hrp-encoded type III protein secretion in Pseudomonas syringae strains. J. Bacteriol. 183:5589-5598.

Laby, R. J., and Beer, S. V. 1992. Hybridization and functional complementation of the hrp gene cluster from Erwinia amylovora strain Ea321 with DNA of other bacteria. Mol. Plant-Microbe Interact. 5:412-419.

Lichter, A., Barash, I., Valinsky, L., and Manulis, S. 1995a. The genes involved in cytokinin biosynthesis in Erwinia herbicola pv. gypsophilae: Characterization and role in gall formation. J. Bacteriol. 177:44574465.

Lichter, A., Manulis, S., Sagee, O., Gafni, Y., Gray, J., Meilan, R., Morris, R. O., and Barash, I. 1995b. Production of cytokinins by Erwinia herbicola pv. gypsophilae and isolation of a locus conferring cytokinin biosynthesis. Mol. Plant-Microbe Interact. 8:114-121.

Lichter, A., Manulis, S., Valinsky, L., Karniol, B., and Barash, I. 1996. IS1327, a new insertion-like element in the pathogenicity-associated plasmid of Erwinia herbicola pv. gypsophilae. Mol. Plant-Microbe Interact. 9:98-104

Lindgren, P. B. 1997. The role of $h r p$ genes during plant-bacterial interactions. Annu. Rev. Phytopathol. 35:129-152.

Lindgren, P. B., Frederick, R., Govindarajan, A. G., Panopoulos, N. J. Staskawicz, B. J., and Lindow, S. E. 1989. An ice nucleation reporter gene system: Identification of inducible pathogenicity genes in Pseudomonas syringae pv. phaseolicola. EMBO (Eur. Mol. Biol. Organ.) J. $8: 1291-1301$

Lonetto, M. A., Brown, K. L., Rudd, K. E., and Buttner, M. J. 1994. Analysis of Streptomyces coelicolor sigE gene reveals the existence of the subfamily of eubacterial RNA polymerase s factors involved in the regulation of extracytoplasmic functions. Proc. Natl. Sci. U.S.A. 91:7573-7577.

Loper, J. E., and Lindow, S. E. 1997. Reporter gene systems useful in evaluating in situ gene expression by soil- and plant-associated bacteria. Pages 482-492. in: Manual of Environmental Microbiology. G. C. Hurst, ed. American Society for Microbiology Press, Washington, DC.

Manulis, S., Gafni, Y., Clark, E., Zutra, D., Ophir, Y., and Barash, I. 1991. Identification of a plasmid DNA probe for detection of Erwinia herbicola pathogenic on Gypsophila paniculata. Phytopathology 81:54-57.

Merighi, M., Majerczak, D. R., von Bodman, S., and Coplin, D. L. 2001. A two-component signal transduction system and quorum sensing regulate the Hrp-type III secretion system in Pantoea stewartii subsp. stewartii. Page 661 in: 10th International Congress on Molecular Plant-Microbe Interactions. Madison, WI, U.S.A.

Miller, W. G., Leveau, J. H. J., and Lindow, S. E. 2000. Improved $g f p$ and inaZ broad host range promoter-probe vectors. Mol. Plant-Microbe Interact. 13:1243-1250.

Mor, H., Manulis, S., Zuc, M., Nizan, R., Coplin, D. L., and Barash, I. 2001. Genetic organization of the $h r p$ gene cluster and dspAE/BF operon in Erwinia herbicola pv. gypsophilae. Mol. Plant-Microbe Interact. 14:431-436

Morret, E., and Segovia, L. 1993. The s54 bacterial enhancer-binding protein family: Mechanisms of action and phylogenetic relationship of their functional domains. J. Bacteriol. 175:6067-6074.

Nizan, R., Barash, I., Valinsky, L., Lichter, A., and Manulis, S. 1997. The presence of hrp genes on the pathogenicity- associated plasmid of the 
tumorigenic bacterium Erwinia herbicola pv. gypsophilae. Mol. PlantMicrobe Interact. 10:677-682.

Nizan-Koren, R., Manulis, S., and Barash, I. 2001. The hrp regulatory cascade of Erwinia herbicola pv. gypsophilae. Abstr. Proc. 10th International Congress on Molecular Plant-Microbe Interactions. Madison, WI, U.S.A.

Opgenorth, D. C., Hendson, T. M., and Clark, E. 1994. First report of a bacterial gall of a Wisteria sinensis caused by Erwinia herbicola pv. milletiae in California. Plant Dis. 78:1217.

Rahme, L. G., Mindrinos, M. N., Panopaulos, N J. 1992. Plants and environmental sensory signals control the expression of hrp genes in Pseudomonas syringe pv. phaseolicola. J. bacteriol. 174:3499-3507.

Sambrook, J., Fritsch, E. F., and Maniatis, T. 1989. Molecular Cloning: A Laboratory Manual. Cold Spring Harbor Laboratory Press, Cold Spring Harbor, NY, U.S.A.

Starr, M. P. 1981. The genus Erwinia. Pages 1260-1271 in: The Prokaryotes. M. P. Starr, H. G. Truper, A. Balows, and H. G. Schlegel, eds. Springer-Verlag, Berlin.

Valinsky, L., Manulis, S., Nizan, R., Ezra, D., and Barash, I. 1998. A pathogenicity gene isolated from the pPATH of Erwinia herbicola pv. gypsophilae determines host specificity. Mol. Plant-Microbe Interact. 11:753-762.

Valinsky, L., Barash, I., Chalupowicz, L., Ezra, D., and Manulis, S. 2002. Regulation of $h s v G$, a host-specific virulence gene from Erwinia herbicola pv. gypsophilae. Physiol. Mol. Plant Pathol. 60:19-29.

Vasanthakumar, A., and McManus, P. C. 2001. Etiology of cranberry stem gall. Abstr. No. 228. 10th International Congress on Molecular
Plant-Microbe Interactions University of Wisconsin, Madison, WI U.S.A.

Volcani, Z. 1985. Page 388 in: Bacterial Diseases of Plants in Israel. Agricultural Research Organization, The Volcani Center, Bet Dagan, Israel.

Wanner, B. L. 1990. Phosphorus assimilation and its control of gene expression in Escherichia coli. In: The Molecular Basis of Bacterial Metabolism. G. Hauska and R. Thauer, eds. Springer-Verlag, Heidelberg, Germany.

Wanner, B. L. 1992. A cross regulation by phosphorylation of two-component response regulator proteins important in bacteria? J. Bacteriol. 174:2053-2058.

Wei, Z. B., and Beer, S. V. 1995. hrpL activates Erwinia amylovora hrp gene transcription and is a member of the ECF subfamily of sigma factors. J. Bacteriol. 177:6201-6210.

Wei, Z. M., Kim, J. F., and Beer, S. V. 2000. Regulation of hrp genes and type III protein secretion in Erwinia amylovora by HrpX/HrpY, a novel two component system, and HrpS. Mol. Plant-Microbe Interact. 13:1251-1262.

Wengelnik, K., and Bonas, U. 1996. HrpXv, an Arac-type regulator, activates expression of five of the six loci in the hrp cluster of Xanthomonas campestris pv. vesicatoria. J. Bacteriol. 178:3462-3469.

Xiao, Y., Heu, S., Jinseong, Y., Lu, Y., and Hutcheson, S. W. 1994. Identification of a putative alternate sigma factor and characterization of a multicomponent regulatory cascade controlling the expression of $P$. syringae pv. syringae Pss61 hrp and hrmA genes. J. Bacteriol. 176:10251036 . 